\title{
Maternal-Fetal Thyroid Interactions
}

\author{
R.G. Ahmed
}

Additional information is available at the end of the chapter

http://dx.doi.org/10.5772/48076

\section{Introduction}

Life is getting complicated in the world of local thyroid hormones (THs) regulation. On account of $\mathrm{TH}$ action can be controlled in individual cells through selective TH uptake and intracellular TH metabolism, the placenta is an important link in the maternal-fetal communication network for THs which are essential for the normal development and differentiation of the fetus [1-3]. Generally, intracellular activation or inactivation of Lthyroxine (T4) and 3,5,3'-triiodothyronine (T3) in turn is determined by three types of iodothyronine deiodinases (Ds), namely DI, DII, and DIII [4-7]. The placenta transports and metabolizes maternal THs, and mainly expresses DIII, which inactivates T4 and other iodothyronines and thus limits the transfer of maternal active THs to the fetus in the late pregnancy [8]. DII is also active in the placenta and locally provides active T3 from the maternal prohormone $\mathrm{T} 4$ for placental metabolic functions [1,2]. The placental expression of DI, which also activates T4 to T3, is still controversial. Because of the lipophilic nature of THs, it was thought that they traversed the plasma membrane by simple diffusion $[9,10]$. The transport of T4 and T3 in and out of cells is controlled by several classes of transmembrane TH-transporters (THTs) [11], including members of the organic anion transporter family (OATP), L-type amino acid transporters (LATs), $\mathrm{Na}^{+} /$Taurocholate cotransporting polypeptide (NTCP), and monocarboxylate transporters (MCTs) $[10,12]$. Particularly, monocarboxylate transporter 8 (MCT8) has recently been identified as an active and specific TH transporter. Also, placental membranes are also involved in 4'-OH-sulfation reactions of iodothyronines [8]. Sulfation (S) plays a role in TH metabolism by interacting between the deiodination and sulfation pathways of TH [13]. Interestingly, placental cells express high affinity, stereo-specific, energy-dependent uptake systems for T4 and T3. On the other hand, the cellular activity of THs is usually classified as genomic (nuclear) and non-genomic (initiated either at cytoplasm or at membrane TH receptors) [14-21]. Binding of T3 to its nuclear thyroid receptors (TRs) directly affects transcription of many genes that are important in development [22]. 
In general, pregnancy is accompanied by profound alterations in the thyroidal economy (hypo- or hyper-thyroidism), resulting from a complex combination of factors specific to the pregnant state, which together concur to stimulate the maternal thyroid machinery $[1,23]$. Also, clinical studies showed that maternal $\mathrm{TH}$ deficiency during the first trimester of pregnancy can affect the outcome of human neurodevelopment [24,25]. Experiments in rats showed that early maternal TH deficiency affects neuronal migration in the cortex [26], while maternal hyperthyroidism too can disturb fetal brain development [27]. Experimental data on the mechanisms regulating intracellular TH availability and action prior to the onset of fetal TH secretion, however, remain scarce. Thus, in this chapter will be aware about the significant roles of THs, their metabolism by Ds and sulfotransferases, their transport by THTs and their binding to TRs from the mother via the placenta to the fetal compartment especially during the gestation period in both human and animals.

\section{Placental transport of thyroid hormones}

\subsection{By thyroid hormone-deiodinases (Table 1 and Figure 1)}

The synthesis of THs is regulated through the hypothalamus-pituitary-thyroid (HPT) axis [28] and the follicular cells of the thyroid gland synthesize and secrete T4 and T3 [1,2,21]. This process is under the control of the circulating TH levels through negative feedback loops of this axis [28]. The availability of the active ligand T3 within tissues is locally determined by the action of the iodothyronine deiodinases (Ds) [29]. There are three selenocysteine monodeiodinase subtypes (DI, DII and DIII) [30]. Whilst T3 is generated by the activity of DI and DII, via 5'- reductive or outer ring deiodination (ORD) of the T4 [31], DIII activity (and to a lesser extent that of DI) convert T4 to 3,3',5'-tri-iodothyronine (reverse T3; rT3) and T3 into 3,3'-T2 via inner ring deiodination (IRD), in effect acting as a deactivating enzyme for THs [13,32].

Activities of all three iodothyronine deiodinase subtypes have been demonstrated in most rat placenta [33]. However, in contrast to man, rodent total serum T3 and T4 increase with gestation [34] and the predominant subtype expressed appears to be DIII [35], although DII is also present with significant activity [36]. Placental DIII activity is much greater (approx. 200 times) than DII activity; however, the activity and expression of both DII and DIII fall as gestation progresses [37-40]. Placental DII provides T3 for 'housekeeping' processes, and as indicated above, its activity is much less than that of D3 [40]. DII has been localized to the villous cytotrophoblasts in the first trimester and syncytiotrophoblasts in the third trimester, whereas DIII has been localized to the villous syncytiotrophoblasts in both the first and third trimesters of pregnancy [39]. Both DIII mRNA and activity are present at the implantation site in rodents, as early as gestational day 9 (GD 9), being expressed in mesometrial and antimesometrial decidual tissue [41]. Also, in rabbit [42] and pig [43], the placenta appears to express DIII activity predominantly. The positioning of the deiodinases, particularly DIII, suggests that they might regulate the amount of maternal $\mathrm{TH}$ reaching fetal circulation [40]. Interestingly, 
however, fetuses with total thyroid agenesis but with evidence of circulating maternal TH have normal placental DIII activity, suggesting that there might be other factors modulating T4 access to the deiodinases, such as intracellular protection of TH by THbinding protein (THBP) [40,44]. Collectively, express placental Ds (II, III) may play a critical role in delivery of $\mathrm{TH}$ to the fetus as summarized in figure $12,45-47]$ and table 1 $[1,2,31,48]$.

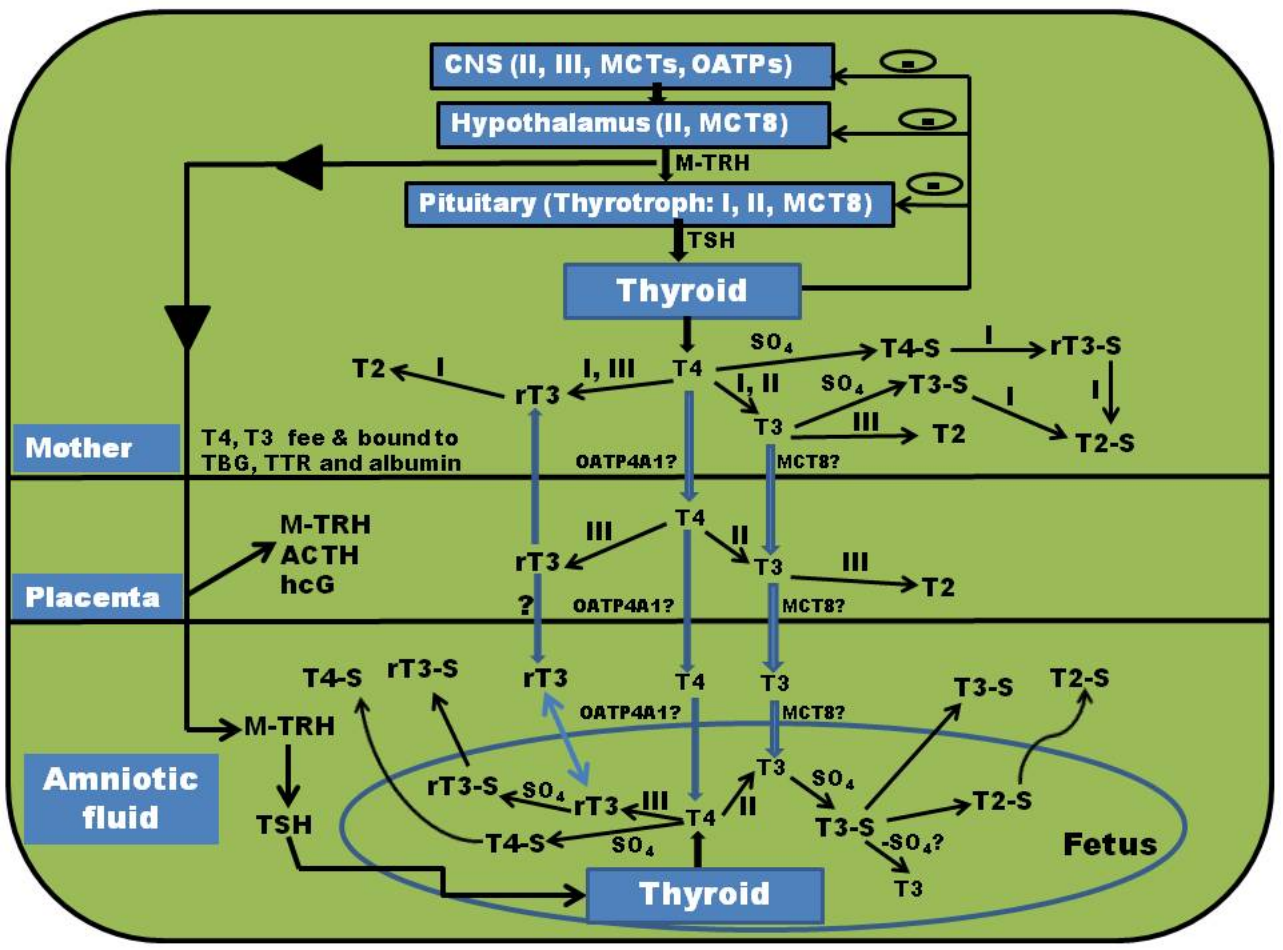

Figure 1. Summary about the interactions of maternal, placental and fetal thyroid metabolism. I, II and III denote deiodinases type 1 (DI), type two (DII) and type three (DIII). $\mathrm{SO}_{4}$ is a sulfation pathway and $-\mathrm{SO}_{4}$ is a desulfation pathway. CNS is central nervous system, TRH is thyroid releasing hormone, M-TRH is maternal thyroid releasing hormone, TSH is thyrotrophin, T2 is diiodothyronine, T3 is triiodothyronine, rT3 is reverse triiodothyronine, T4 is thyroxine, T2S is diiodothyronine sulfate, T3S is triiodothyronine sulfate, T4S is thyroxine sulfate, rT3S is reverse triiodothyronine sulfate, MCT8 is monocarboxylate transporter 8, OATP4A1 is organic anion transporter $4 \mathrm{~A} 1$, TBG is thyroxin binding globulin, TTR is transthyretin, ACTH is adrenocorticotrophin and hCG is human chorionic gonadotrophin. 


\begin{tabular}{|c|c|c|c|}
\hline Characteristic & DI & DII & DIII \\
\hline Reaction kinetics & Ping-pong & \multicolumn{2}{|l|}{ Sequential } \\
\hline $\begin{array}{l}\text { Reaction catalyzed } \\
\text { (Deiodination) }\end{array}$ & 5 or 5 ' (ORD+IRD) & $5^{\prime}$ (ORD) & 5 (IRD) \\
\hline Main form & T4-T3, rT3- T2 & - T4- rT3, T3- T2 & - T4- rT3- T2 \\
\hline Substrate preference & $\begin{array}{l}\text { 5: } \mathrm{T} 4 \mathrm{~S}>\mathrm{T} 3 \mathrm{~S}>>\mathrm{T} 3, \mathrm{~T} 4 \\
\text { 5': } \mathrm{rT3}, \mathrm{rT} 3 \mathrm{~S}>\mathrm{T} 2 \mathrm{~S}>>\mathrm{T} 4\end{array}$ & $\mathrm{~T} 4>\mathrm{rT} 3$ & $\mathrm{~T} 3>\mathrm{T} 4$ \\
\hline Sulfation of substrates & Stimulation & \multicolumn{2}{|l|}{ Inhibition } \\
\hline Substrate limiting $K \mathrm{M}$ & $0.5 \mathrm{mM}$ & $1-2 \mathrm{nM}$ & $5-20 \mathrm{mM}$ \\
\hline $\begin{array}{l}\text { In vitro cofactor limiting } \\
\mathrm{KM}\end{array}$ & 1-10 Mm DTT & $>10 \mathrm{mM}$ DTT & $=70 \mathrm{mM}$ DTT \\
\hline Molecular mass (kDa) & 29 & 30 & 32 \\
\hline Selenocysteine & \multicolumn{3}{|l|}{ present } \\
\hline Homodimer & \multicolumn{3}{|l|}{ Yes } \\
\hline Location & $\begin{array}{l}\text { - Liver, kidney, } \\
\text { thyroid and pituitary. }\end{array}$ & $\begin{array}{l}\text { - Pituitary, brain, } \\
\text { BAT, thyroida, } \\
\text { heart }^{\mathrm{a}} \text { and skeletal } \\
\text { muscle }^{\mathrm{a}} \text {. }\end{array}$ & $\begin{array}{l}\text { - Brain, skin, uterus, } \\
\text { placenta, fetus and } \\
\text { in other sites of the } \\
\text { maternal- fetal } \\
\text { interface, such as } \\
\text { the umbilical } \\
\text { arteries and veins. }\end{array}$ \\
\hline Subcellular location & $\begin{array}{l}\text { - Liver: endoplasmic } \\
\text { reticulum. - kidney: } \\
\text { basolateral plasma } \\
\text { membrane }\end{array}$ & \multicolumn{2}{|c|}{ - Microsomal membranes } \\
\hline Functions & $\begin{array}{l}\text { - Production serum } \\
\text { T3 and the clearance } \\
\text { of serum rT3. }\end{array}$ & $\begin{array}{l}\text { - Catalyzes the } \\
\text { outer ring } \\
\text { deiodination of } \mathrm{T} 4 \\
\text { to T3 and is thus } \\
\text { important for the } \\
\text { local production } \\
\text { of T3. }\end{array}$ & $\begin{array}{l}\text { - Catalyzes the } \\
\text { inner ring } \\
\text { deiodination of T4 } \\
\text { to rT3 and of T3 to } \\
\text { 3,3'-T2. }\end{array}$ \\
\hline $\begin{array}{l}\text { Activity in } \\
\text { hypothyroidism }\end{array}$ & $\begin{array}{l}\text { - Decrease in liver } \\
\text { and kidney. } \\
\text { - increase in thyroid. }\end{array}$ & $\begin{array}{l}\text { - Increase in all } \\
\text { tissues. }\end{array}$ & - Decrease in brain. \\
\hline $\begin{array}{l}\text { Activity in } \\
\text { hyperthyroidism }\end{array}$ & $\begin{array}{l}\text { - Unknown in liver } \\
\text { and kidney. } \\
\text { - Increase in thyroid. }\end{array}$ & $\begin{array}{l}\text { - Decrease in most } \\
\text { tissues. } \\
\text { - Increase in } \\
\text { thyroid }\end{array}$ & - Increase in brain. \\
\hline Low-T3 syndrome & - Decrease & \multicolumn{2}{|l|}{ - No change } \\
\hline
\end{tabular}




\begin{tabular}{|c|c|c|c|}
\hline Active site residues & $\begin{array}{l}\text { - Selenocysteine } \\
\text { histidine and } \\
\text { phenylalanine. }\end{array}$ & - (Seleno-)cysteine? & - Selenocysteine \\
\hline $\begin{array}{l}\text { Human gene structure } \\
\text { and location }\end{array}$ & $\begin{array}{l}\text { - 1p32-p33, } 17.5 \mathrm{~kb} \\
\text { and } 4 \text { exons. }\end{array}$ & $\begin{array}{l}\text { - 14q24.3, } 2 \text { exons, } \\
\text { and 7.4-kb intron. }\end{array}$ & $-14 q 32$ \\
\hline Promoter elements & $\begin{array}{l}\text { - TRE, RXR, no CAAT } \\
\text { or TATA box. }\end{array}$ & -- & \\
\hline $\begin{array}{l}\text { Propylthiouracil } \\
\text { inhibitor }\end{array}$ & \multirow[t]{2}{*}{++++} & + & $+/-$ \\
\hline $\begin{array}{l}\text { Aurothioglucose } \\
\text { inhibitor }\end{array}$ & & \multicolumn{2}{|l|}{++} \\
\hline Iopanoic acid inhibitor & +++ & ++++ & +++ \\
\hline Thiouracils & \multirow[t]{2}{*}{++++} & $-/+$ & - \\
\hline iodoacetate & & + & $?$ \\
\hline flavonoids & + & +++ & \\
\hline
\end{tabular}

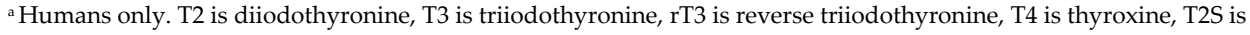
diiodothyronine sulfate, T3S is triiodothyronine sulfate, T4S is thyroxine sulfate, rT3S is reverse triiodothyronine sulfate, ORD is outer ring deiodination, IRD is inner ring deiodination, TRE is T3-responsive element, RXR is retinoid $X$ receptors and DDT is dithiols.

Table 1. General characteristics of the iodothyronine deiodinases.

\subsection{By thyroid hormone-transporters (THTs) (Tables $2 \& 3$ and Figure 1)}

Membrane transporters mediate cellular uptake and efflux of TH $[12,40,49]$. The ability to transport $\mathrm{TH}$ has been described in members of different transporter groups including the monocarboxylate transporters (MCT), L-type amino acid transporters (LAT), $\mathrm{Na}^{+} /$Taurocholate cotransporting polypeptide (NTCP), and organic anion transporting polypeptides (OATP) [50]. With the exception of MCT8, these transporters do not exclusively transport TH and they all have slightly different affinities for specific forms of TH. To date six different THTs are known to be present in the placenta: MCT8, MCT10, LAT1, LAT2, OATP1A2 and OATP4A1 but their relative contributions to placental TH transport are unknown [50-55]. Also, their anatomical localization, ontogeny in the human placenta and relative affinity for the $\mathrm{TH}$ and thyronines are very complex. MCT8, MCT10, OATP1A2, OATP4A1 and LAT1 are expressed in villous syncytiotrophoblasts, and MCT8, MCT10 and OATP1A2 in cytotrophoblasts [50]. Although transporters in the apical syncytiotrophoblast membrane are well placed to maximize maternal cellular TH uptake early in gestation, the large numbers and variety of THTs are intriguing [51,53,55]. Moreover, the expression of MCT8 mRNA increased with advancing gestation [55] but there is limited information regarding the ontogeny of the other THTs. In addition, it is likely that the lower expression of MCT8, MCT10, OATP1A2 and LAT1 before 14 week compared to term, as well as the nadir in OATP4A1 expression in the late $1^{\text {st }}$ and early $2^{\text {nd }}$ trimester, may play a role in the necessary limitation of maternal-fetal $\mathrm{TH}$ transfer, particularly around the time of onset of endogenous fetal $\mathrm{TH}$ production in the early $2^{\text {nd }}$ trimester [56]. Increased expression of THTs in late gestation is consistent with the proposal 
that there is continued/ increased maternal to fetal supply of $\mathrm{TH}$ in the $3^{\text {rd }}$ trimester despite increasing fetal $\mathrm{TH}$ production [57]. It is also likely that increased expression of these transporters with gestation may also fulfil the increased need for other biological substances for fetal growth and development, such as amino acids. The most factors regulating the placental expression of these transporters are unknown until now. There are suggestions in rodents that the activity of system-L and the expression of MCT8 in non-placental tissues are influenced by thyroid status [58] suggesting that TH may be a regulator of its own transporters [50]. During the passage of THs from the maternal circulation to the fetal circulation, each THT is likely to have a specific role in each different plasma membrane layer, which might include cellular influx, efflux, or both [59]. To sum, THTs of the various placental cell types serve as channels that help to maintain the differences in the composition of THs and their metabolites between maternal and fetal circulations (figure1 [2,45-47] and tables 2 \& 3 [51,52,55,59,60,61]). The relative contributions of these THTs to the transplacental transport of thyroid hormones are still a subject for research.

\begin{tabular}{|c|c|c|}
\hline Transporter $^{a}$ & Iodothyronine derivates & Specificity $^{b}$ \\
\hline MCT8 & $\mathrm{T} 3, \mathrm{~T} 4, \mathrm{rT} 3, \mathrm{~T} 2$ & +++ \\
\hline MCT10 & $\mathrm{T} 3, \mathrm{~T} 4$ & ++ \\
\hline OATP1A1 & T3, T4, rT3, T2, T4S, T3S, rT3S, T2S & \multirow[t]{8}{*}{+} \\
\hline OATP1A2 & $\mathrm{T} 4, \mathrm{~T} 3, \mathrm{rT} 3$ & \\
\hline OATP1A3 & \multirow[t]{3}{*}{$\mathrm{T} 4, \mathrm{~T} 3$} & \\
\hline OATP1A4 & & \\
\hline OATP1A5 & & \\
\hline OATP1B1 & T4, T3, T3S, T4S, rT3S & \\
\hline OATP1B2 & $\mathrm{T} 3, \mathrm{~T} 4$ & \\
\hline OATP1B3 & rT3, T4S, T3S, rT3S & \\
\hline OATP1C1 & $\mathrm{T} 4, \mathrm{rT} 3, \mathrm{~T} 3, \mathrm{~T} 4 \mathrm{~S}$ & ++ \\
\hline OATP2B1 & \multirow[t]{2}{*}{$\mathrm{T} 4$} & + \\
\hline OATP3A1 (V1/V2) & & ++ \\
\hline OATP4A1 & $\mathrm{T} 3, \mathrm{~T} 4, \mathrm{rT} 3$ & \multirow[t]{6}{*}{+} \\
\hline OATP4C1 & \multirow[t]{3}{*}{$\mathrm{T} 3, \mathrm{~T} 4$} & \\
\hline OATP6B1 & & \\
\hline OATP6C1 & & \\
\hline LAT1 & \multirow[t]{2}{*}{$\mathrm{T} 3, \mathrm{~T} 4, \mathrm{rT} 3, \mathrm{~T} 2$} & \\
\hline LAT2 & & \\
\hline NTCP & T4, T3, T4S, T3S & ++ \\
\hline
\end{tabular}

${ }^{a}$ The human protein symbol is presented, if TH transport has been demonstrated in different species including humans. ${ }^{b}$ If a transporter only transports iodothyronine derivatives, specificity is high (+++). If fewer than five other ligands are known, specificity is moderate $(++)$. If more than five ligands are known, the transporter is denoted as multispecific $(+)$.

Table 2. Types of thyroid hormone transporters and their iodothyronine derivates. 


\begin{tabular}{|c|c|c|c|c|c|c|}
\hline \multirow[t]{2}{*}{$\begin{array}{l}\text { Transporter } \\
\text { family }\end{array}$} & \multicolumn{2}{|c|}{$\begin{array}{l}\text { Monocarboxylate } \\
\text { transporters }\end{array}$} & \multicolumn{2}{|c|}{$\begin{array}{l}\text { System L amino } \\
\text { acidtransporters }\end{array}$} & \multicolumn{2}{|c|}{$\begin{array}{l}\text { Organic anion } \\
\text { transporting } \\
\text { polypeptides } \\
\end{array}$} \\
\hline & MCT8 & MCT10 & LAT1 & LAT2 & OATP1A2 & OATP4A1 \\
\hline Heterodimer & \multicolumn{2}{|c|}{ N/A } & \multicolumn{2}{|c|}{$4 \mathrm{~F} 2 \mathrm{hc}$} & \multicolumn{2}{|c|}{$\mathrm{N} / \mathrm{A}$} \\
\hline $\begin{array}{l}\text { Additional } \\
\text { molecules } \\
\text { transported }\end{array}$ & N/A & $\begin{array}{l}\text { Aromatic } \\
\text { amino } \\
\text { acids }\end{array}$ & \multicolumn{2}{|c|}{$\begin{array}{l}\text { Large neutral } \\
\text { amino acids }\end{array}$} & \multicolumn{2}{|c|}{$\begin{array}{l}\text { Amphipathic organic } \\
\text { compounds }\end{array}$} \\
\hline $\begin{array}{l}\text { Localization in } \\
\text { first and second } \\
\text { trimester }{ }^{\mathrm{a}}\end{array}$ & $\begin{array}{c}\text { ST, CT, } \\
\text { EVT }\end{array}$ & \multicolumn{5}{|c|}{ N/A } \\
\hline $\begin{array}{l}\text { Localization in } \\
\text { third trimester }\end{array}$ & ST & $\mathrm{N} / \mathrm{A}$ & STap & \multicolumn{2}{|c|}{$\mathrm{N} / \mathrm{A}$} & STap \\
\hline $\mathrm{Km} \mathrm{T4}(\mu \mathrm{M})$ & $4.7^{\mathrm{c}}$ & $>\mathrm{Km} \mathrm{T}^{\mathrm{d}}$ & \multicolumn{2}{|c|}{7.9} & 8.0 & $>\mathrm{Km} \mathrm{T3}$ \\
\hline $\mathrm{Km}$ T3 $(\mu \mathrm{M})$ & $4.0^{c}$ & $\leq 4.0^{\mathrm{d}}$ & \multicolumn{2}{|c|}{0.8} & 6.5 & 0.9 \\
\hline $\mathrm{Km} \mathrm{rT3}(\mu \mathrm{M})$ & $2.2^{\mathrm{c}}$ & N/A & \multicolumn{2}{|c|}{12.5} & \multicolumn{2}{|c|}{ N/A } \\
\hline $\mathrm{Km}$ T2 $(\mu \mathrm{M})$ & \multicolumn{2}{|c|}{$\mathrm{N} / \mathrm{A}$} & 7.9 & \multicolumn{3}{|c|}{ N/A } \\
\hline
\end{tabular}

aOnly MCT8 has been localized in the placenta in all three trimesters of pregnancy. ${ }^{\mathrm{b}}$ LAT1 and OATP4A1 have been localized only at term. ${ }^{c}$ These $\mathrm{Km}$ values were determined for the rat MCT8 protein expressed in Xenopus laevis oocytes. The other $\mathrm{Km}$ values shown are mainly from studies using the human gene expressed in X. laevis oocytes. dHuman MCT8 or MCT10 transporters expressed in COS1 cells both showed a greater preference for T3 than T4 uptake. Whereas MCT10 showed a greater capacity than MCT8 to transport T3, MCT8 was found to be a more active transporter of $\mathrm{T} 4$.

Abbreviations: CT is cytotrophoblast cells, EVT is extravillous trophoblast cells, N/A is no data available, rT3 is reverse T3, ST is syncytiotrophoblast layer and ST ${ }^{\text {ap }}$ is predominantly at apical surface of the ST.

Table 3. Expression of the thyroid hormone transporters in human placenta.

\subsection{By thyroid hormone-sulfotransferases (Figure 1)}

Sulfation (S) appears to be an important pathway for the reversible inactivation of THs during fetal development [2,13,45-47]. Monique Kester and the group from Erasmus University have used a rat model to study the regulation of fetal TH status and have also extended their studies to human pregnancy [62]. The sulfotransferases catalyze the sulfation of the hydroxyl group of compounds, using 3'-phosphoadenosine-5'-phosphsulfate (PAPS) as the universal sulfate donor [63]. This co-factor PAPS is synthesized from two ATP molecules and inorganic sulfate. Neither the DII or DIII iodothyronines catalyze the deiodination of sulfated iodothyronines nor sulfation strongly facilitates the inner ring deiodination of T4 and T3 by DI, but blocks the outer ring deiodination of T4 (activation) $[13,64]$. The outer ring deiodination of rT3 by DI is not affected by sulfation [64]. Sulfation thus induces the irreversible degradation of TH. Thus, rapid inner ring deiodinations of T4S, T3S and out ring deiodination of rT3S lead to high concentrations of these sulfates in plasma of adult humans $[13,65]$. 
High concentrations of the different iodothyronine sulfates, T4S (thyroxine sulfate), T3S (triiodothyronine sulfate), rT3S (reverse triiodothyronine sulfate) and T2S (diiodothyronine sulfate), have been documented in human fetal and neonatal plasma as well as in amniotic fluid [65,66], and similar findings have been reported for sheep [67]. This has classically been explained by the low hepatic DI expression in the human fetus until the postnatal period [68] and lack of hepatic DI expression until birth in rats [69]. Also, in the rat placenta, where there are insignificant sulfotransferases activities but high DIII activity, irreversible inactivation of DIII appears to be the predominant pathway of iodothyronine metabolism [13]. In the rat fetal liver, sulfotransferase activity is present from the end of the third trimester (GD 17), a time when DI activity is relatively absent [69]. The TH-sulfates may accumulate under such circumstances to form a 'reservoir' of inactive TH from which active hormone may be liberated, in a tissue specific and gestational dependent manner by the action of arylsulfases [13]. To date, six members of this family (ARSAeARSF) have been identified in humans $[13,70]$. It is interesting that DIII is abundantly expressed in the human placenta [39] and deiodinates T4 and T3 to 3,3'-T2 and rT3, respectively, thus providing substrates for these actions. In the human fetal circulation, T4S and in particular T3S, may represent a reservoir of inactive $\mathrm{TH}$, from which active hormone may be liberated as required (vide supra) [13]. The iodothyronine sulfates in human fetal circulation and amniotic fluid may be derived, at least in part, from sulfation of THs by thermostabile phenol sulfotransferases in the uterus and placenta $[13,45]$. This may provide a route for the supply of maternal $\mathrm{TH}$ to the fetus in addition to placental transfer. Alternatively, iodothyronine sulfates may accumulate in the fetal circulation because of the absence of hepatic transporters which mediate their removal from plasma. It has been demonstrated recently that hepatic uptake of the different iodothyronine sulfates in rats is mediated at least in part through the NTCP and OATP families [71]. Thus, the TH-sulfation mechanism might be useful for non-invasive prenatal diagnostics of fetal thyroid function which is autonomously regulated. The overviews presented here are consistent with the evolving view that sulfation is a major chemical defense system in the maternal-fetal thyroid axis and will hopefully provide a basis for understanding more about these enzymes.

\subsection{By thyroid hormone-genomic and non-genomic actions (Tables $4 \& 5$ and Figure 2)}

Although the thyroid gland predominantly secretes T4, T3 is the most active TH, since it has a higher affinity by the nuclear thyroid hormone receptors (TRs; $\alpha, \beta$ ) (Figure 2A) [75], which mediate most actions of these hormones [72,73]. THs are released by the thyroid gland to the circulation where they are carried bound to proteins such as thyroxin binding globulin (TBG), transthyretin (TTR) or serum albumin (Table 4) [74]. The level of albumin, which has the lowest T4 affinity and enables a fast release of T4 [76], gradually decreases during pregnancy [77]. TBG is an active carrier and has a possibility to switch between the high-affinity and the low-affinity form [78]. TBG levels are the highest in the second and third trimester of pregnancy $[79,80]$ and the same holds true for TH-binding ratio [81] and thyroid-binding capacity [82], which decreases as soon as 3-4 days after delivery. 
(A)

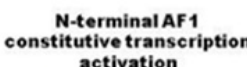

DNA

Hinge
domain

C-terminal AF 2

activation
active transcription

domain domain

Homo and Hetero dimerization

Ligand dependent transcriptional activation

\section{Ligand}

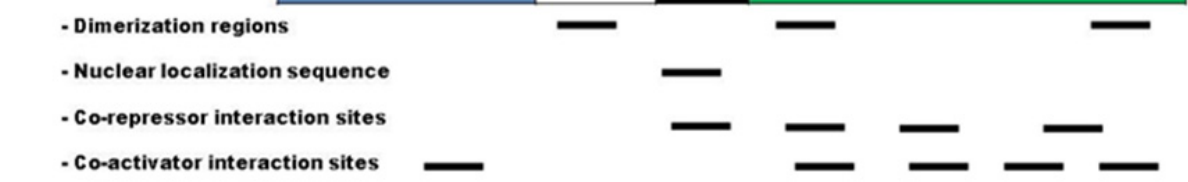

(B)

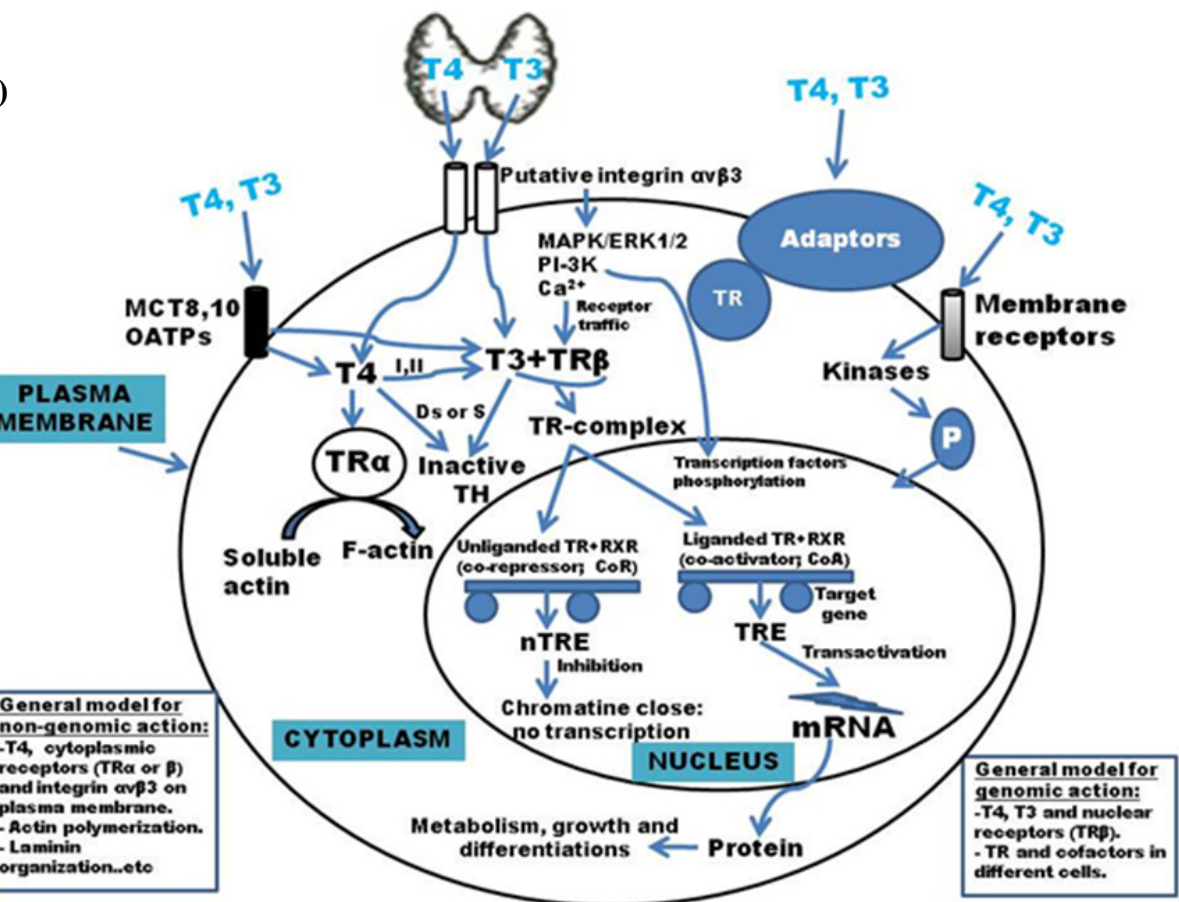

Abbreviations: T3 is triiodothyronine, T4 is thyroxine, TR is thyroid hormone receptor, RXR is retinoid X receptors, TRE is T3-responsive element, nTRE is none T3-responsive element, Ds is deiodonases, $\mathrm{S}$ is sulfotransferases, MCT is monocarboxylate transporter, OATP is organic anion transporter, MAPK/ERK1/2 is mitogen-activated protein kinase, $\mathrm{P}$ is phosphorylation and PI-3K is phosphatidylinositol 3-kinase.

Figure 2. (A) Schematic representation of major thyroid hormone receptors $(\operatorname{TR} \alpha, \beta)$ domains and functional sub-regions. (B) General model for genomic and non-genomic actions of TH in both adult and fetus; Schematic representation of thyroid hormones (THs; T4 and T3) genomic actions, initiated at the nuclear receptors (TR $\beta$ ), and non-genomic actions, initiated at cytoplasmatic receptors (TR $\beta$, TR $\alpha$ ) and at the plasma membrane on the membrane receptors, particularly integrin $\alpha \mathrm{v} \beta 3$ receptor. T4 binding (but not T3) to cytoplasmic TR $\alpha$ may cause a change of state of actin. T3 binding (but not T4) to cytoplasmic TR $\beta$ activates the phosphatidylinositol 3-kinase (PI-3K) pathway leading to alteration in membrane ion pumps and to transcription of specific genes. TH binding to the integrin receptor results in activation of mitogen-activated protein kinase (MAPK/ERK1/2). Phosphorylated MAPK (pMAPK) translocates to the nucleus where it phosphorylates transcription factors including thyroid receptors (TR $\beta$ ), estrogen receptor (ER) and signal transducer activators of transcription (STAT). Generally, activity is regulated by an exchange of corepressor (CoR) and coactivator $(\mathrm{CoA})$ complexes. 


\begin{tabular}{|l|c|}
\hline \multicolumn{1}{|c|}{ TH-binding protein } & Cellular location \\
\hline Transthyretin & \\
\hline T4-binding globulin & \\
\hline Serum albumin & \\
\hline Lipoproteins & \\
\hline Myosin light chain kinase & \\
\hline Pyruvate kinase, subtype M1 & \\
\hline Pyruvate kinase, subtype M2 & \\
\hline Prolyl 4-hydroxylase, b-subunit & \\
\hline Aldehyde dehydrogenase & \\
\hline
\end{tabular}

Table 4. Types of thyroid hormone-binding proteins.

\subsubsection{General genomic action (Table 5 and Figure 2)}

T4 and T3 enter the cell through transporter proteins such as MCT8 and 10 or OATPs. Inside the cells, deiodinases (DI, II) convert T4, the major form of thyroid hormone in the blood, to the more active form T3. DIII produces rT3 and T2 from T4 and T3, respectively $[1,73,83]$. T3 binds to nuclear TRs, TR $\alpha$ and TR $\beta$, that activate transcription by binding, generally as heterodimers with the retinoid $X$ receptor (RXR) (Table 5) [87], to thyroid hormone response elements (TREs) located in regulatory regions of target genes [84]. Activity is regulated by an exchange of corepressor (CoR) and coactivator (CoA) complexes. Negative TREs (nTRE) can mediate ligand-dependent transcriptional repression, although in this case the role of coactivators and corepressors is not well defined [73,85]. TRs can also regulate the activity of genes that do not contain a TRE through "cross-talk" with other transcription factors (TF) that stimulate target gene expression $[28,86]$. Both receptors and coregulators are targets for phosphorylation $(\mathrm{P})$ by signal transduction pathways stimulated by hormones and growth factors $[84,85]$. Thus, the nuclear actions of T3 are sensitive to inhibitors of transcription and translation and have a latency of hours to days $[9,73]$. Thus, the genomic action will play a critical role in the cellular proliferations and differentiations.

\subsubsection{General non-genomic action (Table 5 and Figure 2)}

Although T3 is known to exert many of its actions through the classical genomic regulation of gene transcription, a number of T3 effects occur rapidly and are unaffected by inhibitors of transcription and protein synthesis $[88,89]$. However, the levels of circulating THs are tightly regulated and stable and thus rapidly mediated responses must involve regulation of pre-receptor ligand metabolism, ligand membrane transport or receptor availability leading to local cell type specific variation in thyroid hormone signaling [87]. Non-genomic actions of THs have been described at the plasma membrane, in the cytoplasm and in cellular organelles $[15,21,83,90,91]$. They have included the modulation of $\mathrm{Na}^{+}, \mathrm{K}^{+}, \mathrm{Ca}^{2+}$ and glucose transport, activation of protein kinase C (PKC), protein kinase A (PKA) and mitogenactivated protein kinase (ERK/MAPK) and regulation of phospholipid metabolism by 
activation of phospholipase C (PLC) and D (PLD) [92-94]. Generally, binding of T3 to a subpopulation of receptors located outside the nuclei can also cause rapid "non-genomic" effects through interaction with adaptor proteins, leading to stimulation of signaling pathways. T4 can also bind to putative membrane receptors such as integrin receptor $(\alpha \mathrm{V} \beta 3)$ inducing MAPK activity $[18,73,95,96]$. Thus, several observations suggest that the rapid nongenomic effects of $\mathrm{TH}$ are widespread and may be involved in multiple physiological processes in many different cell types [87]. However, no specific membrane associated TR isoform or thyroid hormone binding G protein-coupled receptors (GPCR) have been identified or cloned and thus the area remains controversial.

\begin{tabular}{|c|c|c|c|c|c|}
\hline Compare face & Ligand & Receptor & $\begin{array}{c}\text { Dimerization } \\
\text { partners }\end{array}$ & $\begin{array}{l}\text { Associated factors or } \\
\text { signalling pathways }\end{array}$ & Actions \\
\hline \multicolumn{6}{|c|}{ Classical, genomic actions (hours to days) } \\
\hline \multirow[t]{2}{*}{$\begin{array}{l}\text { Nuclear } \\
\text { transcription }\end{array}$} & \multirow[t]{2}{*}{ T3 } & \multirow[t]{2}{*}{$\begin{array}{l}\mathrm{TR} \alpha \text { and } \\
\operatorname{TR} \beta\end{array}$} & \multirow[t]{2}{*}{$\begin{array}{l}\text { RXR and } \\
\text { TRs }\end{array}$} & - NCoR/SMRT Basal & $\begin{array}{l}\text { - Transcriptional } \\
\text { repression }\end{array}$ \\
\hline & & & & - SRC/p160/TRAPs & $\begin{array}{l}- \text { Transcriptional } \\
\text { activation and } \\
\text { repression }\end{array}$ \\
\hline \multicolumn{6}{|c|}{ Non-classical non-genomic actions (seconds to minutes) } \\
\hline \multirow[t]{2}{*}{$\begin{array}{l}\text { Cell surface } \\
\text { receptor }\end{array}$} & \multirow[t]{2}{*}{$\mathrm{T} 4 / \mathrm{T} 3$} & \multirow[t]{2}{*}{$\begin{array}{l}\text { Putative } \\
\text { GPCR }\end{array}$} & & Raf1/MEK/MAPK & $\begin{array}{l}\text { TR phosphorylation } \\
\text { and altered } \\
\text { transcriptional } \\
\text { activity p53 } \\
\text { phosphorylation and } \\
\text { general transcriptional } \\
\text { activity }\end{array}$ \\
\hline & & & & MEK/STATs & $\begin{array}{l}\text { Increased STAT } \\
\text { mediated } \\
\text { transcription }\end{array}$ \\
\hline $\begin{array}{l}\text { Mitochondrial } \\
\text { gene } \\
\text { transcription }\end{array}$ & T3 & TR $\alpha \mathrm{p} 43$ & $\begin{array}{l}\text { mtRXR and } \\
\text { mtPPAR }\end{array}$ & Co-factors? & $\begin{array}{l}\text { Increased } \\
\text { mitochondrial gene } \\
\text { expression }\end{array}$ \\
\hline \multirow[t]{2}{*}{$\begin{array}{l}\text { Mitochondrial } \\
\text { oxidation }\end{array}$} & T3 & TR $\alpha$ p28 & & ANT, UCPs & $\begin{array}{l}\begin{array}{l}\text { Increased } \\
\text { thermogenesis }\end{array} \\
\end{array}$ \\
\hline & $\mathrm{T} 2$ & $\begin{array}{l}\text { Cytochrome } \\
-c \mathrm{Va}\end{array}$ & & & $\begin{array}{l}\text { Increased oxidative } \\
\text { phosphorylation }\end{array}$ \\
\hline
\end{tabular}

Abbreviations: T4 is Thyroxine, T3 is triiodothyronine, T2 is diiodothyronine, RXR is retinoid X receptor, TR is thyroid hormone receptor, GPCR is G protein coupled receptor, $\mathrm{mtRXR}$ is mitochondrial retinoid X receptor $\alpha$ isoform, $\mathrm{mtPPAR}$ is mitochondrial peroxisome proliferator activator receptor $\gamma 2$ isoform, NCoR is nuclear receptor corepressor, SMRT is silencing mediator of RAR and TR, SRC is steroid receptor cooactivator, TRAPs is thyroid receptor associated protein, Raf1 is Raf serine/threonine kinase, MEK is mitogen activated protein kinase kinase, MAPK is mitogen activated protein kinase, STAT is signal transducers and activators of transcription, ANT is adenine nucleotide translocase and UCP is uncoupling protein.

Table 5. General thyroid hormone actions. 
There also are reports of nongenomic effects on cell structure proteins by THs. Actin depolymerization blocks DII inactivation by T4 in cAMP-stimulated glial cells, suggesting that an intact actin cytoskeleton is important for this downregulation of deiodinase activity [9,97]. Interestingly, T4, but not T3, can promote actin polymerization in astrocytes [98] and thus may influence the downregulation of DII activity by a secondary mechanism, perhaps by targeting to lysosomes [9,99]. Moreover, the regulation of actin polymerization and F-actin contents also could contribute to the effects of $\mathrm{TH}$ on arborization, axonal transport, and cell-cell contacts during brain development, where the regulation of these factors is fundamental for the organization of guidance molecules such as laminin on the astrocyte plasma membrane and modulates integrin-laminin interactions [3]. T4 was required for integrin clustering and attachment to laminin by integrin in astrocytes [100]. These data suggest that the non-genomic action may play an important role in promoting the normal development.

\section{Maternal-fetal thyroid in normal state}

THs are essential for normal neonatal development in both humans and rodents [3,23,101-104] and the experimental work indicated that THs are transported from the mother to the fetus, albeit in limited amounts, and that the fetal brain is exposed to THs before initiation of fetal $\mathrm{TH}$ synthesis [1]. In addition, the maternal TH regulates early fetal brain development in human and animal models [2]. The TH of maternal origin can cross the placenta and reach the fetus $[2,105,106]$ and that TRs are expressed in the fetal rat brain before the onset of fetal thyroid function [107]. Thus, the THs are essential for brain maturation from early embryonic stages onward [103,104,108]. However, TH-dependent stages of fetal brain development remain to be characterized. Notably, the maternal thyroid is the only source of T4 and T3 for the brain of the fetus because its thyroid gland does not start contributing to fetal requirements until midgestation in man, and days 17.5-18 in rats [109]. Therefore, the amount of maternal $\mathrm{T} 4$ that the fetus receives early in pregnancy will determine $\mathrm{TH}$ action in its brain because it depends on maternal T4 for its intracellular supply of the active form of the hormone, T3. However, fetal brain total T3 levels are low (ca. $100 \mathrm{pM}$ ) at this time [1], but receptor occupancy approximates $25 \%$ since free $\mathrm{T} 3$ concentrations are high in the nucleus relative to the cytosol [110]. In general, materno-fetal transfer of THs has been demonstrated in early fetal stages [111] and continues, at least in the case of fetal inability, to produce sufficient TH until term [44]. Actually, brain cells can protect themselves against higher fetal T4 and T3 values by decreasing DII and increasing DIII activity [2]. Taken together, thyroid activity undergoes many changes during normal pregnancy including [1,112-115]: (a) a significant increase in serum thyroxine-binding globulin, thyroglobulin, total T4, and total T3; (b) an increase in renal iodide clearance; and (c) stimulation of the thyroid by human chorionic gonadotropin (hCG). These changes can make diagnosis of thyroid dysfunction during pregnancy difficult.

\section{Maternal-fetal thyroid in hypothyroid state}

THs are important for growth and differentiation of a variety of organs, including the brain. In developing brain, THs stimulate and coordinate processes such as neuronal proliferation, migration, growth of axons and dendrites, synapse formation and myelination [1,2]. 
Disturbance of these processes leads to abnormalities in the neuronal network and may result in mental retardation and other neurological defects, including impaired motor skills and visual processing [115]. If $\mathrm{TH}$ deficiency occurs at the perinatal stage, such as in congenital hypothyroidism, timely treatment may rescue most of the symptoms. A shortage of THs starting at the early stages of pregnancy, such as in cretinism, results in neurological deficits that cannot be rescued by exogenous TH addition at later stages [25].

The role of THs in brain development has been studied most extensively in the cerebellum $[23,116]$. The cellular proliferation and migration processes are disturbed by TH deficiency as investigated predominantly in rodents, where most of cerebellar maturation occurs in the early postnatal period [2]. In the hypothyroid cerebellum, the number and length of Purkinje cell dendrites is severely reduced [1]. At the same time the granule cell parallel fiber growth is reduced, leading to a reduction in axodendritic connections between the Purkinje cells and the granule neurons [117]. Additionally, other cell types such as astrocytes, Golgi epithelial cells, basket cells, and oligodendrocytes show abnormalities under hypothyroid conditions [116]. Several TH target genes have been identified over the years, including genes coding for myelin proteins, cytoskeletal proteins, neurotrophins and their receptors, transcription factors, and intracellular signaling proteins [118] and recent transcriptome analyses continue to increase their number [119-121]. Some of these genes only respond to thyroid status for a short and specific period during development, a feature that is typical for many TH target genes in brain [122]. Interestingly, a reduction or absence of TH during brain maturation yields molecular, morphological and functional alterations in the cerebral cortex, hippocampus and cerebellum [123-132].

\section{Maternal-fetal thyroid in hyperthyroid state (Figure 3)}

Neonatal hyperthyroidism was described as a critical disease marked mainly by cardiac symptoms, poor weight gain and severe neurological manifestations [1,133-137]. Fetal thyrotoxicosis is the result of thyroid-stimulating antibody transfer to the fetus in the setting of maternal Grave's disease [2,138]. It may present with a variety of clinical features, which include persistent sinus tachycardia, fetal hydrops, intrauterine growth restriction, goiter and fetal demise [1,139]. The vast majority of cases of excessive serum $\mathrm{TH}$ concentration seen in pregnancy are due to the overproduction of THs (Graves' disease, toxic nodular goiter); in the postpartum period, thyrotoxicosis may be due to exacerbation of Graves' hyperthyroidism or to the release of thyroid hormone due to an acute autoimmune injury to the thyroid tissue (postpartum thyroiditis-PPT) [2,140].

The management of hyperthyroidism in pregnancy, which most often is caused by Graves' disease, has been reviewed recently [141,142]. Hyperthyroidism occurs in about $0.2-0.4 \%$ of all pregnancies. Hyperthyroidism should be distinguished from gestational transient thyrotoxicosis, which is due to the TSH-receptor stimulating effects of hCG [143,144]. This hCGinduced hyperthyroidism is mostly mild and need not be treated. Only rare cases with extremely high hCG (i.e. due to a hydatidiform mole) might induce severe thyrotoxicosis [145]. The signs and symptoms of hyperthyroidism due to Graves' disease may aggravate in the first trimester and thereafter may become mild. Untreated hyperthyroidism is associated with severe 
effects on maternal and neonatal outcome. The risk for premature fetal loss, preeclampsia, preterm delivery, intrauterine growth retardation and low birth weight is significantly increased [144]. It has to be considered that the transfer of stimulating receptor antibodies (TSAbs) are transferred from the mother to the child, and therefore the fetus is at risk to develop Graves' disease. Close monitoring of the fetus is, therefore, strictly recommended, even in mothers treated by thyroidectomy before pregnancy but have still elevated TSAbs [142].

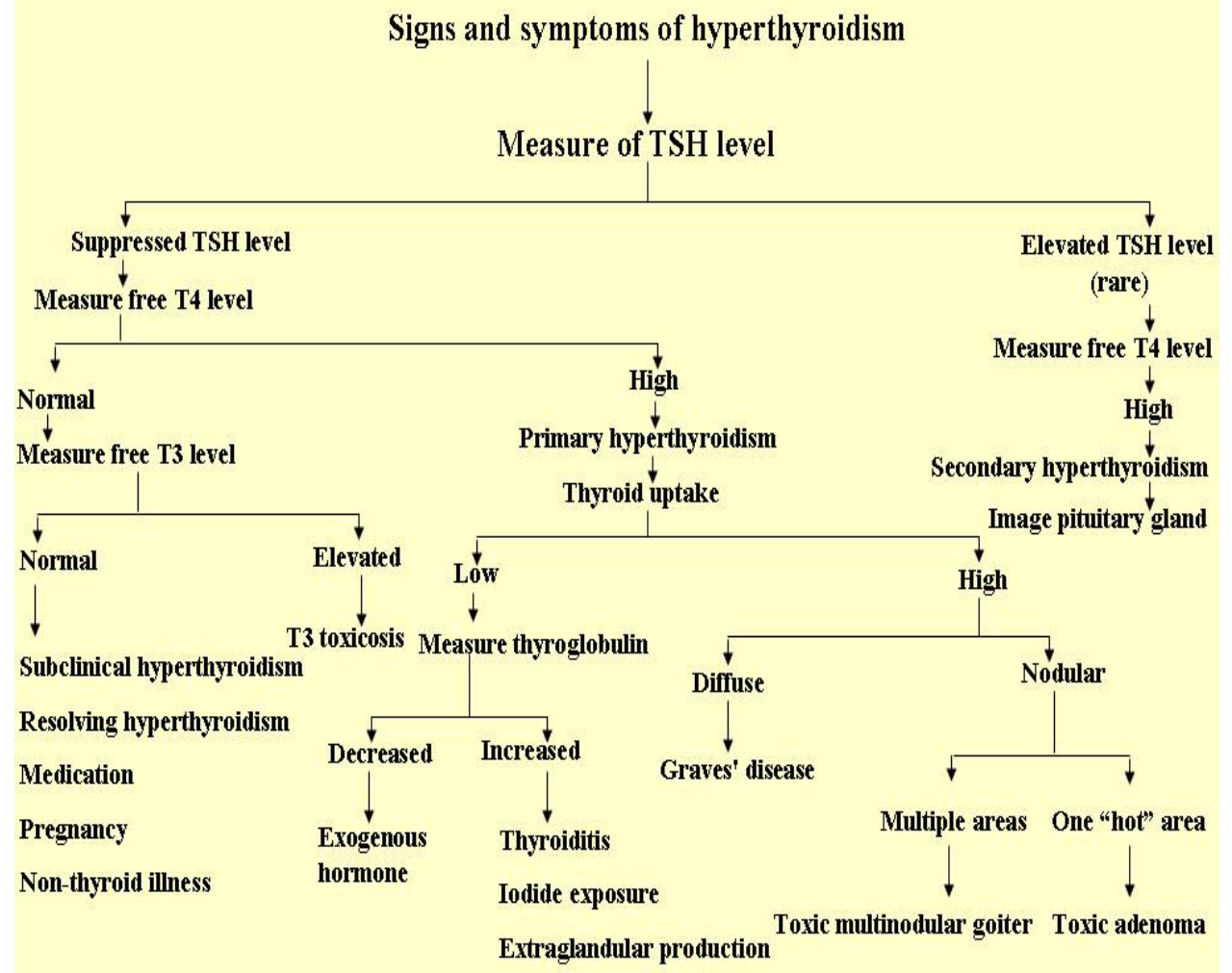

Figure 3. Different cases of hyperthyroidism.

Taken together, there are two known causes of central hyperthyroidism [1,146]; (1) TSHproducing pituitary tumors (TSHomas) and (2) the syndrome of pituitary resistance to thyroid hormone (PRTH). In general, thyrotoxicosis is the syndrome resulting from an excess of circulating free T4 and/or free T3 $[147,148]$. Babies likely to become hyperthyroid have the highest TSH receptor antibody titer whereas if TSH receptor antibodies are not detectable, the baby is most unlikely to become hyperthyroid (Figure 3) $[1,2,149]$. In the latter case, it can be anticipated that the baby will be euthyroid, have transient hypothalamic-pituitary suppression or have a transiently elevated TSH, depending on the relative contribution of maternal hyperthyroidism versus the effects of maternal antithyroid medication, respectively [150]. 


\section{Summary}

about the developmental thyroid hormone mechanisms (deiodinases, transporters, sulfotransferases and receptors) in human [1,2,50,52,127,130,151-154], rat [1,2,41,60,135,154156] and chicken [7,157-170]. Note that the chicken is born early compared to the rat and human, as well as the rat is born early compared to the human (Table 6).

\begin{tabular}{|c|c|c|c|c|c|}
\hline & Human & \multicolumn{2}{|c|}{ Rodent (rat) } & \multicolumn{2}{|r|}{ Chicken } \\
\hline \multicolumn{2}{|c|}{ Week post conception } & \multicolumn{2}{|c|}{ Day post conception } & \multicolumn{2}{|r|}{ Incubation day } \\
\hline $1 \mathrm{~W}$ & $\begin{array}{l}\text { - DIII is detected } \\
\text { in uterine wall. }\end{array}$ & $1 \mathrm{GD}$ & $\begin{array}{l}\text { DII and DIII are } \\
\text { observed in } \\
\text { uterine wall. }\end{array}$ & $\begin{array}{l}5 \mathrm{~h} \\
\text { (blastula } \\
\text { stage) }\end{array}$ & $\begin{array}{l}\text { - TR } \alpha \text { mRNA is noticed and } \\
\text { the levels markedly increased } \\
\text { during neurulation. }\end{array}$ \\
\hline $3 \mathrm{~W}$ & $\begin{array}{l}\text { - Thyroid gland } \\
\text { begins. }\end{array}$ & $\begin{array}{l}7-8.5 \\
\text { GD }\end{array}$ & $\begin{array}{l}\text { - Time of } \\
\text { implantation } \\
\text { process. } \\
\text { - Very high DIII } \\
\text { activity is } \\
\text { detected in } \\
\text { decidual tissue. }\end{array}$ & $24 \mathrm{~h}$ & $\begin{array}{l}\text { - mRNA levels of DI, DII and } \\
\text { DIII are detected in whole } \\
\text { embryos. }\end{array}$ \\
\hline $4-6 \mathrm{~W}$ & $\begin{array}{l}\text { - TBG is observed } \\
\text { in thyroid follicle } \\
\text { cells at GD } 29 . \\
\text { - TRH is detected } \\
\text { in fetal whole- } \\
\text { brain at } 4.5 \text { weeks } \\
\text { of gestation. } \\
\text { - T4 is transferred } \\
\text { via the placenta } \\
\text { and has been } \\
\text { found in the } \\
\text { gestational fluid } \\
\text { sac from } 4 \text { to } 6 \mathrm{~W} .\end{array}$ & \multirow[t]{2}{*}{$9 \mathrm{GD}$} & \multirow[t]{2}{*}{$\begin{array}{l}\text { - Thyroid gland } \\
\text { is first visible as } \\
\text { an endodermal } \\
\text { thickening in the } \\
\text { primitive buccal } \\
\text { cavity. } \\
\text { - TH is detected } \\
\text { in rat } \\
\text { embryotrophobl } \\
\text { asts }\end{array}$} & \multirow[t]{2}{*}{$48 \mathrm{~h}$} & \multirow[t]{2}{*}{$\begin{array}{l}\text { - OATP1c1 expression } \\
\text { appears. }\end{array}$} \\
\hline $\begin{array}{l}5-11 \\
W\end{array}$ & $\begin{array}{l}\text { - Maternal-embryo } \\
\text { transfer of THs has } \\
\text { been detected in } \\
\text { embryonic } \\
\text { coelomic fluid and } \\
\text { amniotic fluid. } \\
\text { - All the mRNAs } \\
\text { encoding THTs } \\
\text { are expressed in } \\
\text { placenta from } 6 \mathrm{~W} \\
\text { and throughout } \\
\text { pregnancy. }\end{array}$ & & & & \\
\hline
\end{tabular}




\begin{tabular}{|c|c|c|c|c|c|}
\hline $8 \mathrm{~W}$ & $\begin{array}{l}\text { - T4, T3 and rT3 } \\
\text { are detected in } \\
\text { coelomic/amniotic } \\
\text { fluids. } \\
\text { - TRs, DII and DIII } \\
\text { are noticed in } \\
\text { fetal brain. }\end{array}$ & 10 GD & $\begin{array}{l}-\mathrm{T} 4, \mathrm{~T} 3 \text { and } \mathrm{TR} \beta \\
\text { are detected in } \\
\text { embryo/trophobl } \\
\text { ast unit. }\end{array}$ & E2-E4 & $\begin{array}{l}\text { - T3, THTs, Ds and TRs are } \\
\text { expressed in whole embryos. }\end{array}$ \\
\hline $10 \mathrm{~W}$ & $\begin{array}{l}\text { - TSH is first } \\
\text { detected in the } \\
\text { fetal pituitary. }\end{array}$ & & & E4 & $\begin{array}{l}\text { - OATP1c1 expression is } \\
\text { more than } 10 \text {-fold higher in } \\
\text { the telencephalon and } \\
\text { diencephalon compared to } \\
\text { the mesencephalon and } \\
\text { rhombencephalon. } \\
\text { - DII mRNA levels are } \\
\text { highest in the diencephalon. }\end{array}$ \\
\hline $\begin{array}{l}8-10 \\
W\end{array}$ & $\begin{array}{l}\text { - The fetus is able } \\
\text { to produce THs } \\
\text { during this } \\
\text { period, but prior } \\
\text { to that time, is } \\
\text { totally dependent } \\
\text { on maternal THs. }\end{array}$ & & & E5 & $\begin{array}{l}\text { - TR } \alpha \text { mRNA is widely } \\
\text { distributed in fore-, mid- and } \\
\text { hind-brain. }\end{array}$ \\
\hline $11 \mathrm{~W}$ & $\begin{array}{l}\text { - TBG levels are } \\
\text { detected in fetal } \\
\text { serum and } \\
\text { increased through } \\
\text { gestation. }\end{array}$ & & & E6 & $\begin{array}{l}\text { - } \mathrm{T} 4 \text { and } \mathrm{T} 3 \text { are detected in } \\
\text { embryonic brain. }\end{array}$ \\
\hline $\begin{array}{l}8-11 \\
W\end{array}$ & $\begin{array}{l}\text { - TRH is detected } \\
\text { in fetal } \\
\text { hypothalamus. }\end{array}$ & & & E7 & $\begin{array}{l}\text { - DII activity is observed in } \\
\text { the brain before the onset of } \\
\text { thyroid function and } \\
\text { increases significantly. }\end{array}$ \\
\hline $12 \mathrm{~W}$ & $\begin{array}{l}\text { - T4 and T3 are } \\
\text { observed in serum } \\
\text { and brain. } \\
\text { - Total serum T4 } \\
\text { and T3 are low, } \\
\text { free T4 is } \\
\text { relatively high. } \\
\text { - rT3 is noticed in } \\
\text { serum relatively } \\
\text { high. } \\
\text { - TH synthesis } \\
\text { begins in fetal } \\
\text { thyroid. }\end{array}$ & 13 GD & $\begin{array}{l}\text { - Placental } \\
\text { circulation } \\
\text { established. } \\
\text { - TRs and TH are } \\
\text { observed in fetal } \\
\text { brain. } \\
\text { - DIII and DII are } \\
\text { detected in } \\
\text { uterus and } \\
\text { placenta. }\end{array}$ & E8 & $\begin{array}{l}\text { - DII mRNA is noticed in cell } \\
\text { clusters throughout the } \\
\text { brain, particularly in } \\
\text { rhombencephalon. } \\
\text { - OATP1c1 levels are } \\
\text { declined substantially in all } \\
\text { brain regions. }\end{array}$ \\
\hline
\end{tabular}




\begin{tabular}{|c|c|c|c|c|c|}
\hline & $\begin{array}{l}\text { - Decreased } \\
\text { mRNA expression } \\
\text { of OATP1A2 but } \\
\text { no change for } \\
\text { OATP4A1 at } 9-12 \\
\text { W compared to } \\
\text { term. }\end{array}$ & & & & \\
\hline \multirow[t]{2}{*}{$14 \mathrm{~W}$} & \multirow[t]{2}{*}{$\begin{array}{l}\text { - Expressions of } \\
\text { mRNAs encoding } \\
\text { MCT8, MCT10, } \\
\text { OATP1A2 and } \\
\text { LAT1 are } \\
\text { significantly } \\
\text { lower prior to } 14 \\
\text { W compared to } \\
\text { term }\end{array}$} & 14 GD & $\begin{array}{l}\text { - TRH mRNA is } \\
\text { detected in } \\
\text { neurons of the } \\
\text { fetal } \\
\text { hypothalamus. }\end{array}$ & E4-E8 & $\begin{array}{l}\text { - DIII mRNA levels are } \\
\text { markedly different in the } \\
\text { telencephalon and } \\
\text { diencephalon but remain } \\
\text { stable, while the levels in } \\
\text { mesencephalon and } \\
\text { rhombencephalon show a } \\
\text { sharp decrease and increase, } \\
\text { respectively, during these } \\
\text { days. }\end{array}$ \\
\hline & & 15 GD & $\begin{array}{l}\text { - Pituitary TSH } \\
\text { mRNA } \\
\text { expression } \\
\text { begins. } \\
\text { - TRH mRNA is } \\
\text { detected in the } \\
\text { developing } \\
\text { paraventricular } \\
\text { nuclei of the } \\
\text { hypothalamus. }\end{array}$ & E9-10 & $\begin{array}{l}\text { - Several elements of the } \mathrm{TH} \\
\text { action cascade are present in } \\
\text { the brain of embryos long } \\
\text { before their own thyroid } \\
\text { gland starts hormone } \\
\text { secretion. }\end{array}$ \\
\hline $16 \mathrm{~W}$ & $\begin{array}{l}\text { - DIII is observed } \\
\text { in placenta and } \\
\text { fetal epithelial } \\
\text { cells. } \\
\text { - DIII and TRs are } \\
\text { detected in fetal } \\
\text { liver. } \\
\text { - DI is noticed in } \\
\text { heart and lung. } \\
\text { - Significant fetal } \\
\text { TH secretion } \\
\text { begins. }\end{array}$ & $\begin{array}{l}16-19.5 \\
\text { GD }\end{array}$ & $\begin{array}{l}\text { - TRs are } \\
\text { observed in liver, } \\
\text { heart and lung. } \\
\text { - DI and DII are } \\
\text { noticed in fetal } \\
\text { tissues. } \\
\text { - TRH is } \\
\text { produced in low } \\
\text { levels in } \\
\text { hypothalamus } \\
\text { and increases } \\
\text { approximately } \\
\text { threefold by } \\
\text { GDI9.5. } \\
\end{array}$ & E10 & $\begin{array}{l}\text { - The thyroid gland is fully } \\
\text { functional. }\end{array}$ \\
\hline $\begin{array}{l}16-20 \\
W\end{array}$ & $\begin{array}{l}\text { - Duplication of } \\
\text { TBG } \\
\text { concentrations. }\end{array}$ & 17 GD & $\begin{array}{l}\text { - TH synthesis } \\
\text { begins in fetal } \\
\text { thyroid }\end{array}$ & E13 & $\begin{array}{l}\text { - Brain DII is elevated at the } \\
\text { peak of neuroblast } \\
\text { proliferation. }\end{array}$ \\
\hline
\end{tabular}




\begin{tabular}{|c|c|c|c|c|c|}
\hline & & & $\begin{array}{l}\text { - TSH protein and } \\
\text { Sulfotransferase } \\
\text { are observed. }\end{array}$ & & \\
\hline & & $\begin{array}{l}18-22 \\
\text { GD }\end{array}$ & $\begin{array}{l}\text { - The total T4 and } \\
\text { T3 concentrations } \\
\text { in fetuses are } \\
\text { increased drama- } \\
\text { tically because of } \\
\text { maturation of } \\
\text { hormone } \\
\text { synthesis of the } \\
\text { fetal thyroid } \\
\text { gland. } \\
\text { - The } \\
\text { coordination } \\
\text { between THTs } \\
\text { and Ds is } \\
\text { regulated both } \\
\text { transplacental } \\
\text { TH passage from } \\
\text { mother to fetus } \\
\text { and the } \\
\text { development of } \\
\text { the placenta itself } \\
\text { through the } \\
\text { progress of } \\
\text { gestation. }\end{array}$ & E14 & $\begin{array}{l}\text { - The strong increase in } \\
\text { intracellular T3 has been } \\
\text { observed. }\end{array}$ \\
\hline $20 \mathrm{~W}$ & $\begin{array}{l}\text { - A steady } \\
\text { increase in serum } \\
\text { TH levels begins } \\
\text { and continues to } \\
\text { term. }\end{array}$ & 19 GD & $\begin{array}{l}\text { - Significant fetal } \\
\text { TH secretion } \\
\text { begins. } \\
\text { - Marked rise in } \\
\text { serum TH but } \\
\text { levels at birth } \\
\text { still below those } \\
\text { in adult. }\end{array}$ & E15 & $\begin{array}{l}\text { - Plasma T4 levels start rising } \\
\text { markedly around this day. }\end{array}$ \\
\hline $\begin{array}{l}22-32 \\
W\end{array}$ & $\begin{array}{l}\text { - Serum total and } \\
\text { free T4 and T3 } \\
\text { near and below } \\
\text { adult levels, } \\
\text { respectively. } \\
\text { - The HPT axis } \\
\text { begins to mature } \\
\text { during the second } \\
\text { half of gestation. }\end{array}$ & $22 \mathrm{GD}$ & $\begin{array}{l}\text { - Birth state. } \\
\text { - Thyroid system } \\
\text { is less } \\
\text { developed. } \\
\text { - As much as } \\
17.5 \% \text { of THs } \\
\text { found in the } \\
\text { newborn are of } \\
\text { maternal origin. }\end{array}$ & E16 & $\begin{array}{l}\text { - The decrease in DI activity } \\
\text { in gonads is combined with } \\
\text { the relatively high DIII } \\
\text { activity. } \\
\text { - A significant increase in T3 } \\
\text { production and in DII-activity } \\
\text { and -mRNA expression are } \\
\text { combined with a decreased in } \\
\text { DIII activity. }\end{array}$ \\
\hline
\end{tabular}




\begin{tabular}{|c|c|c|c|c|c|}
\hline & $\begin{array}{l}\text { - LAT1 and } \\
\text { OATP4A1 have } \\
\text { been localized } \\
\text { only during the } \\
\text { third trimester. }\end{array}$ & & & & \\
\hline \multirow[t]{4}{*}{$40 \mathrm{~W}$} & \multirow{4}{*}{$\begin{array}{l}\text { - Birth state. } \\
\text { - Complete } \\
\text { maturation of } \\
\text { thyroid system. } \\
\text { - MCT8 has been } \\
\text { localized in the } \\
\text { placenta in all } \\
\text { three trimesters of } \\
\text { pregnancy. } \\
\text { - High } \\
\text { concentrations of } \\
\text { the different } \\
\text { iodothyronine } \\
\text { sulfates, T4S, T3S, } \\
\text { rT3S and T2S, } \\
\text { have been } \\
\text { documented in } \\
\text { human fetal and } \\
\text { neonatal plasma } \\
\text { as well as in } \\
\text { amniotic fluid } \\
\text { during the } \\
\text { pregnancy. }\end{array}$} & 10 PND & $\begin{array}{l}\text { - Brain } \\
\text { development } \\
\text { equivalent to } \\
\text { human birth. }\end{array}$ & $\begin{array}{l}\text { E13/14- } \\
\text { E17 } \\
\text { (synapt } \\
\text { ogenesis } \\
\text { ) }\end{array}$ & $\begin{array}{l}\text { - Brain DII activity is } \\
\text { moderately elevated, } \\
\text { whereas DIII activity and } \\
\text { mRNA expression are } \\
\text { highest between these days, } \\
\text { followed by a dramatic } \\
\text { decrease thereafter. }\end{array}$ \\
\hline & & $\begin{array}{l}10-20 \\
\text { PND }\end{array}$ & $\begin{array}{l}\text { - Serum TH } \\
\text { levels continue } \\
\text { to rise and are } \\
\text { higher than } \\
\text { adult levels } \\
\text { between these } \\
\text { days. }\end{array}$ & E18 & $\begin{array}{l}\text { - DI and DIII are expressed in } \\
\text { the granule cells, whereas DII } \\
\text { is found mostly in the } \\
\text { molecular layer and the } \\
\text { Purkinje cells at that time. }\end{array}$ \\
\hline & & \multirow[t]{2}{*}{$\begin{array}{l}14-50 \\
\text { PND }\end{array}$} & \multirow{2}{*}{$\begin{array}{l}\text { - The levels of } \\
\text { pituitary and } \\
\text { serum TSH } \\
\text { slowly decrease } \\
\text { from PND 14-16 } \\
\text { until reaching } \\
\text { adult levels at } \\
\text { PND 40. } \\
\text { - TRH levels } \\
\text { increase to adult } \\
\text { levels by PNDI7- } \\
\text { 29, then decrease } \\
\text { transiently } \\
\text { between PND } \\
31-41 \text {; adult } \\
\text { levels are once } \\
\text { again reached at } \\
\text { PND 50. } \\
\text { - Adult TRH } \\
\text { mRNA } \\
\text { expression } \\
\text { patterns are } \\
\text { present at PND } \\
\text { 22. }\end{array}$} & E19 & $\begin{array}{l}\text { - The increase in brain T3 } \\
\text { production correlates with } \\
\text { the appearance of TR } \beta \\
\text { expression in the cerebellum, } \\
\text { telencephalon and optic } \\
\text { lobes. }\end{array}$ \\
\hline & & & & $\begin{array}{l}\text { E20 (at } \\
\text { the } \\
\text { moment } \\
\text { of } \\
\text { pipping } \\
\text { ) }\end{array}$ & $\begin{array}{l}\text { - The brain is quite well } \\
\text { developed at the time of } \\
\text { hatching. } \\
\text { - The gradual increases in } \\
\text { plasma T4 and hepatic DI are } \\
\text { detected. } \\
\text { - DIII levels are decreased in } \\
\text { spleen and increased in skin } \\
\text { and the lungs towards } \\
\text { hatching. } \\
\text { - T3 production seems to be } \\
\text { elevated markedly in liver. } \\
\text { - The rise of T4 is much more } \\
\text { pronounced than in plasma. } \\
\text { - Diminished T4 sulfation is } \\
\text { detected. }\end{array}$ \\
\hline
\end{tabular}




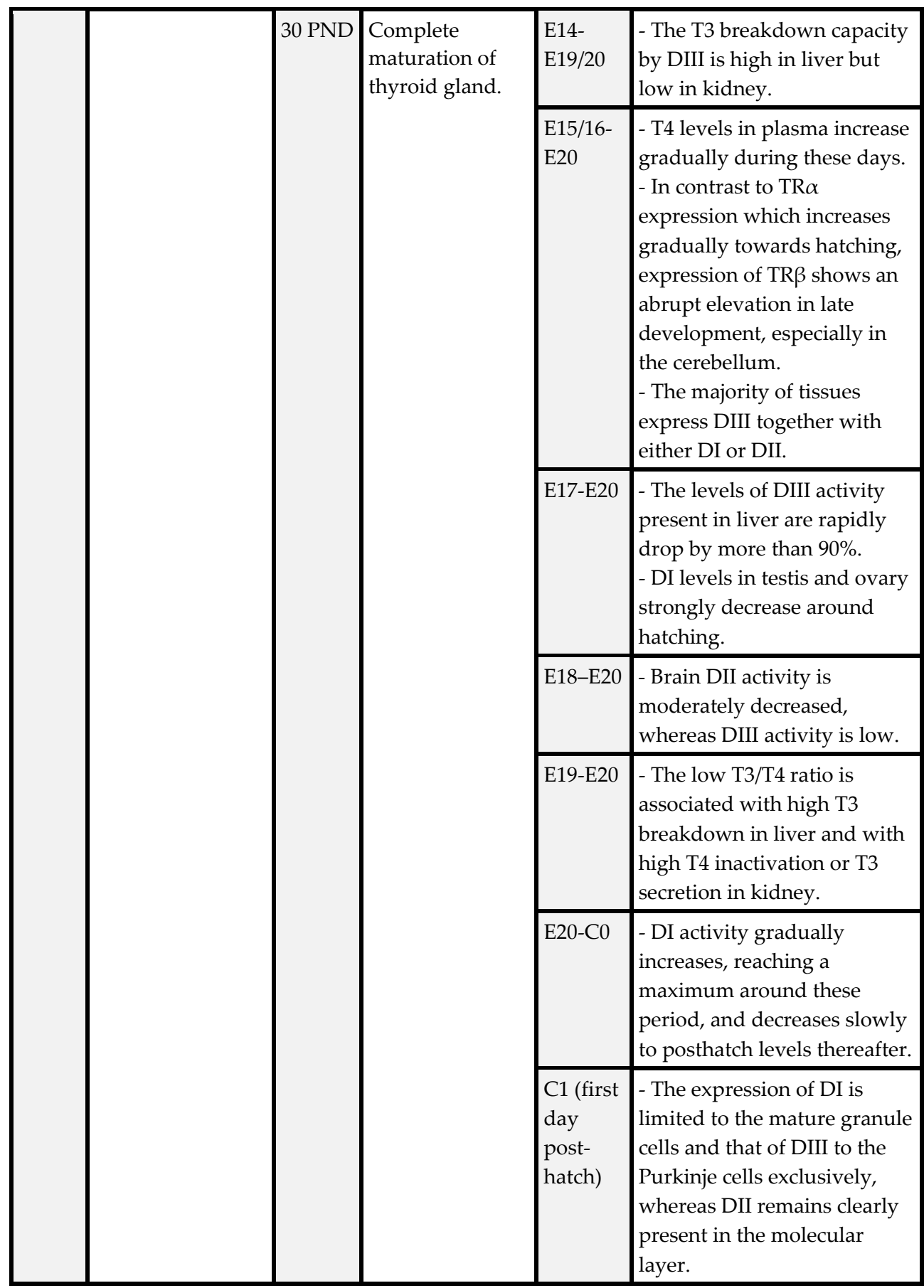




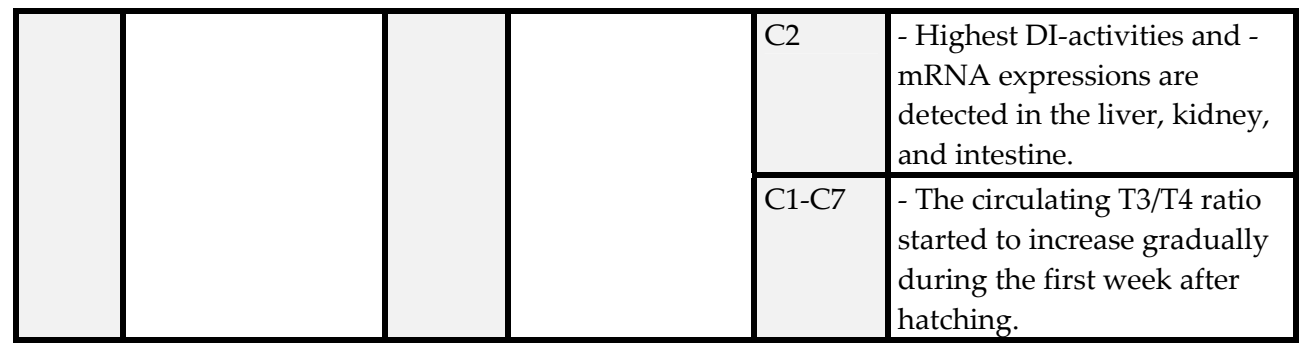

Abbreviations: $\mathrm{W}$ is week, GD is gestation day, $\mathrm{E}$ is incubation day, PND is postnatal day, C is posthatch day, THs is thyroid hormones, TRH is thyroid releasing hormone, TSH is thyroid stimulating hormone, THTs is thyroid hormone transporters, MCT is monocarboxylate transporter, OATP is organic anion transporter, Ds is deiodinases (DI, II, III), TRs is thyroid hormone receptors (TR $\alpha, \beta)$, T4 is Thyroxine, T3 is triiodothyronine, rT3 is reverse triiodothyronine, T2S is diiodothyronine sulfate, T3S is triiodothyronine sulfate, T4S is thyroxine sulfate, rT3S is reverse triiodothyronine sulfate, HPT is hypothalamic-pituitary-thyroid axis and TBG is thyroxin binding globulin.

Table 6. Summary about the developmental thyroid hormone mechanisms (deiodinases, transporters, sulfotransferases and receptors) in human, rat and chicken.

\section{Conclusion}

The actions of THs are highly pleiotropic, affecting many tissues at different developmental stages. As a consequence, their effects on proliferation and differentiation are highly heterogeneous depending on the cell type, the cellular context, and the developmental or transformation status.

Maternal THs are important in promoting normal fetal development especially the placental and CNS development. Clinical epidemiological and basic findings clearly show that maintaining normal $\mathrm{TH}$ regulation from the beginning of pregnancy is important to reduce the risk of obstetric complications and to ensure optimal neurodevelopment of the offspring.

In normal pregnancy, transplacental TH passage is modulated by plasma membrane THTs, Ds, sulfotransferases, TRs and several different proteins within placental cells.

In pathological/abnormal pregnancies with either maternal or fetal THs disturbances (hypoor hyper-thyroidism), the placenta lacks the full compensatory mechanisms necessary to optimize the maternal-fetal transfer of THs to achieve the normality of $\mathrm{TH}$ levels in the fetus.

\section{Future challenges}

Further studies are still needed to improve our understanding of the mechanisms mediating the transplacental transport of THs in both human and animals, particularly the role of the different THTs, and the mechanisms that ensure that sufficient amounts of THs are protected from D3 inactivation during their transit across the placenta. Such knowledge would facilitate the development of interventions to increase $\mathrm{TH}$ passage in pathological situations, in order to ensure normal fetal development. A better understanding of these mechanisms would also permit us to refine the timing and dosage of the increase in 
levothyroxine therapy in hypothyroid pregnant women and to establish whether thyroxine on its own is indeed the best form of TH replacement in pregnancy.

Elucidation of tissue-, cell-, and sex-specific expression of individual Ds and THTs during the development of both human and animals, in the adult, during aging and when sick.

I hope that new insights into the complex actions by which the THs and their receptors control cell proliferation and differentiation will be provided in the near future.

\section{Author details}

R.G. Ahmed

Division of Anatomy and Embryology, Zoology Department, Faculty of Science, Beni-Suef University, Egypt

\section{References}

[1] Ahmed OM, El-Gareib AW, El-bakry AM, Abd El-Tawab SM, Ahmed RG. Thyroid hormones states and brain development interactions. Int. J. Dev. Neurosci. 2008;26 (2):147-209. Review.

[2] Ahmed RG. Effects of experimentally-induced hypothyroidism and hyperthyroidism in pregnant albino rats on the development of their offspring. PhD. Thesis, Fac. of Sci., Beni-Suef Univ., Egypt 2009.

[3] Scapin S, Leoni S, Spagnuolo S, Gnocchi D, De Vito P, Luly P, Pedersen JZ, Incerpi S. Short-term effects of thyroid hormones during development: Focus on signal transduction. Steroids 2010;75:576-584.

[4] Incerpi S, Scapin S, D'Arezzo S, Spagnuolo S, Leoni S. Short-term effect of thyroid hormone in prenatal development and cell differentiation. Steroids 2005;70:434-443.

[5] Gereben B, Zeold A, Dentice M, Salvatore D, Bianco AC. Activation and inactivation of thyroid hormone by deiodinases: local action with general consequences. Cell. Mol. Life Sci. 2008;65:570-590.

[6] Horn S, Heuer H 2010. Thyroid hormone action during brain development: more questions than answers. Mol. and Cell. Endocrinol. 2010;315:19-26.

[7] Van Herck SLJ, Geysens S, Delbaere J, Tylzanowski P, Darras VM. Expression profile and thyroid hormone responsiveness of transporters and deiodinases in early embryonic chicken brain development. Mol. and Cell. Endocrinol. 2012;349(2):289-297.

[8] Köhrle J. Transfer and metabolism of thyroid gland hormones in the placenta. Acta Med. Austriaca 1997;24(4):138-143.

[9] Yen PM. Physiological and molecular basis of thyroid hormone action. Physiol. Rev. 2001;81(3):1097-1126.

[10] Suzuki T, Abe T. Thyroid hormone transporters in the brain. Cerebellum 2008;75-83.

[11] Incerpi S, De Vito P, Luly P, Spagnuolo S, Leoni S. Short-term effects of thyroid hormones and 3,5-diiodothyronine on membrane transport systems in chick embryo hepatocytes. Endocrinol. 2002;143:1660-1668. 
[12] Visser WE, Friesema EC, Jansen J, Visser TJ. Thyroid hormone transport in and out of cells. Trends Endocrinol. Metab. 2008;19:50-56.

[13] Kilby MD, Barber K, Hobbs E, Franklyn JA. Thyroid Hormone Action in the Placenta. Placenta 2005;26:105-113.

[14] D'Arezzo S, Incerpi S, Davis FB, Acconcia F, Marino M, Farías RN, Davis PJ. Rapid nongenomic effects of 3,5,3'-triiodo L-thyronine on the intracellular $\mathrm{pH}$ of L-6 myoblasts are mediated by intracellular calcium mobilization and kinase pathways. Endocrinol. 2004;145:5694-5703.

[15] Incerpi S 2005. Editorial. Thyroid hormones: rapid reply by surface delivery only. Endocrinol. 2005;146 (7):2861-2863.

[16] Farias NR, Fiore AM, Pedersen JZ, Incerpi S. Nongenomic actions of thyroid hormones: Focus on membrane transport systems. Immun. Endocr. Metab. Agents in Med. Chem. 2006;6:241-254.

[17] Pinto M, Soares P, Ribatti D. Thyroid hormone as a regulator of tumor induced angiogenesis. Cancer Letters 2011;301:119-126. Mini-review

[18] Incerpi S. Abstract: at the $90^{\text {th }}$ annual Meeting of the Endocrine Society, San Francisco 2008.

[19] Incerpi S, Davis PJ, De Vito P, Farias RN, Lin H-Y, Davis FB. Nongenomic actions of thyroid hormones and intracellular calcium metabolism. Clin. Rev. Bone \& Miner. Metab. 2008;6(1-2):53-61.

[20] Incerpi S, De Vito P, Pedersen JZ, Luly P. Extranuclear Effects of Thyroid Hormones in Skeletal Muscle. Immun. Endocr. Metab. Agents Med. Chem. 2011;11:188-198.

[21] Incerpi S. Editorial. Nongenomic effects of thyroid hormones in skeletal muscle and central nervous system: from zebrafish to man. Immun. Endocr. Metab. Agents Med. Chem. 2011;11:150-151.

[22] Harvey CB, Williams GR. Mechanism of thyroid hormone action. Thyroid 2002;12:441446.

[23] Ahmed RG. Perinatal 2,3,7,8-tetrachlorodibenzo-p-dioxin exposure alters developmental neuroendocrine system. J. of Food and Chemical Toxicol. 2011;49:12761284.

[24] Pop VJ, Kuijpens JL, van Baar AL, Verkerk G, van Son MM, de Vijlder JJ, Vulsma T, Wiersinga WM, Drexhage HA, Vader HL. Low maternal free thyroxine concentrations during early pregnancy are associated with impaired psychomotor development in infancy. Clin. Endocrinol. (Oxf) 1999;50:149-155.

[25] Pop VJ, Brouwers EP, Vader HL, Vulsma T, van Baar AL, de Vijlder JJ. Maternal hypothyroxinaemia during early pregnancy and subsequent child development: a 3year follow-up study. Clin. Endocrinol. 2003;59:282-288.

[26] Lavado-Autric R, Auso E, Garcia-Velasco JV, Arufe Mdel C, Escobar del Rey F, Berbel P, Morreale de Escobar G. Early maternal hypothyroxinemia alters histogenesis and cerebral cortex cytoarchitecture of the progeny. J. Clin. Invest. 2003;111:1073-1082.

[27] Evans IM, Pickard MR, Sinha AK, Leonard AJ, Sampson DC, Ekins RP. Influence of maternal hyperthyroidism in the rat on the expression of neuronal and astrocytic cytoskeletal proteins in fetal brain. Endocrinol. 2002;175:597-604. 
[28] Sirakov M, Plateroti M. The thyroid hormones and their nuclear receptors in the gut: From developmental biology to cancer. Biochimica et Biophysica Acta 2011;1812:938946.

[29] Berry MJ, Banu L, Larsen PR. Type 1 iodothyronine deiodinase is a selenocysteinecontaining enzyme. Nature 1991;349(6308):438-440.

[30] St. Germain DL, Galton VA. The deiodinase family of selenoproteins. Thyroid 1997;7(4):655-668.

[31] Köhrle J. Local activation and inactivation of thyroid hormones: the deiodinase family. Mol. and Cell. Endocrinol. 1999;15:103-119.

[32] Visser TJ, Schoenmakers CH. Characteristics of type III iodothyronine deiodinases. Acta Medica Austriaca 1992;19:18-21.

[33] Bates JM, St. Germain DL, Galton VA. Expression profiles of the three iodothyronine deiodinases, D1, D2 and D3, in the developing rat. Endocrinol. 1999;140(2):844-851.

[34] Obregon MJ, Mallol J, Morreale de Escobar G, Escobar del Rey F. The presence of thyroxine and tri-iodothyronine in tissues of thyroidectomised rats. Endocrinol. 1981;109:908-913.

[35] Roti E, Fang SL, Braverman LE, Emerson CH. Rat placenta is an active site of inner ring deiodination of thyroxine and 3,3',5-triiodothyronine. Endocrinol. 1982;110:34-37.

[36] Kaplan MM, Shaw EA. Type II iodothyronine 5'-deiodination by human and rat placentas in vitro. J. of Clin. Endocrinol. and Metab. 1984;59:253-257.

[37] Koopdonk-Kool JM, de Vijlder JJ, Veenboer GJ, Ris-Stalpers C, Kok JH, Vulsma T, Boer $\mathrm{K}$, Visser TJ. Type II and type III deiodinase activity in human placenta as a function of gestational age. J. Clin. Endocrinol. Metab. 1996;81:2154-2158.

[38] Stulp MR, Vijlder JJ, Ris-Stalpers C.. Placental iodothyronine deiodinase III and II ratios, mRNA expression compared to enzyme activity. Mol. Cell. Endocrinol. 1998;142:67-73.

[39] Chan S, Kachilele S, Hobbs E, Bulmer JN. Iodothyronine deiodinase expression and activity in human placenta: the effects of intrauterine growth restriction. J. Clin. Endocrinol. Metab. 2003;88:4488-4495.

[40] Patel J, Landers K, Li H, Mortimer RH, Richard K. Delivery of maternal thyroid hormones to the fetus. Trends in Endocrinol. \& Metab. 2011;22(5):164-170.

[41] Galton VA, Martinez E, Hernandez A, St. Germain EA, Bates JM, St. Germain DL. Pregnant rat uterus expresses high levels of the type 3 iodothyronine deiodinase. J. Clin. Invest. 1999;103:979-987.

[42] Brzezinska-Slebodzinska E, Slebodzinski AB, Krysin E. Placental outer and inner ring monodeiodination of thyroxine and triiodothyronines in the rabbit. J. of Dev. Physiol. 1989;11(6):351-353.

[43] Krysin E, Brzezinska-Slebodinska E, Slebodzinski AB. Divergent deiodination of thyroid hormones in the separated parts of the fetal and maternal placenta in pigs. Endocrinol. 1997;155(2):295-303.

[44] Vulsma T, Gons M, de Vijlder JJM. Materno-fetal transfer of thyroxine in congenital hypothyroidism due to a total organification defect or thyroid agenesis. N. Engl. J. Med. 1989;321:13-16. 
[45] Burrow GN, Fisher DA, Larsen PR. Maternal and fetal thyroid function. N. Engl. J. Med. 1994;331:1072-1078.

[46] Bianco, AC, Salvatore D, Gereben B, Berry MJ, Larsen PR. Biochemistry, Cellular and Molecular Biology, and Physiological Roles of the Iodothyronine Selenodeiodinases. Endocr. Rev. 2002;23:38-89.

[47] James SR, Franklyn JA, Kilby MD. Placental transport of thyroid hormone. Best Pract. \& Res. Clin. Endocrinol. \& Metab. 2007;21(2):253-264.

[48] St. Germain DL, Galton VA, Hernandez A. Minireview: Defining the Roles of the Iodothyronine Deiodinases: Current Concepts and Challenges. Endocrinol. 2009;150:1097-1107.

[49] Hennemann G, Docter R, Friesema EC, de Jong M, Krenning EP, Visser TJ. Plasma membrane transport of thyroid hormones and its role in thyroid hormone metabolism and bioavailability. Endocr. Rev. 2001;22:451-476.

[50] Loubière LS, Vasilopoulou E, Bulmer JN, Taylor PM, Stieger B, Verrey F, McCabe CJ, Franklyn JA, Kilby MD, Chan S-Y. Expression of thyroid hormone transporters in the human placenta and changes associated with intrauterine growth restriction. Placenta 2010;31: 295-304.

[51] Ritchie JW, Taylor PM. Role of the System L permease LAT1 in amino acid and iodothyronine transport in placenta. Biochem. J. 2001;356:719-725.

[52] Patel P, Weerasekera N, Hitchins M, Boyd CA, Johnston DG, Williamson C. Semi quantitative expression analysis of MDR3, FIC1, BSEP, OATP-A, OATP-C, OATP-D, OATP-E and NTCP gene transcripts in $1^{\text {st }}$ and $3^{\text {rd }}$ trimester human placenta. Placenta 2003;24:39-44.

[53] Sato K, Sugawara J, Sato T, Mizutamari H, Suzuki T, Ito A. Expression of organic anion transporting polypeptide E (OATP-E) in human placenta. Placenta 2003;24:144-148.

[54] Park SY, Kim J-K, Kim IJ, Choi BK, Jung KY, Lee S. Reabsorption of neutral amino acids mediated by amino acid transporter LAT2 and TAT1 in the basolateral membrane of proximal tubule. Arch Pharm. Res. 2005;28: 421-432.

[55] Chan SY, Franklyn JA, Pemberton HN, Bulmer JN, Visser TJ, McCabe CJ. Monocarboxylate transporter 8 expression in the human placenta: the effects of severe intrauterine growth restriction. Endocrinol. 2006;189:465-471.

[56] de Escobar GM, Obregon MJ, del Rey FE. Maternal thyroid hormones early in pregnancy and fetal brain development. Best Pract. Res. Clin. Endocrinol. Metab. 2004;18:225-248.

[57] Fisher DA. Fetal thyroid function: diagnosis and management of fetal thyroid disorders. Clin. Obstet. Gynecol. 1997;40:16-31.

[58] Capelo LP, Beber EH, Fonseca TL, Gouveia CH. The monocarboxylate transporter 8 and L-type amino acid transporters 1 and 2 are expressed in mouse skeletons and in osteoblastic MC3T3-E1 cells. Thyroid 2009;19:171-180.

[59] Chan SY, Vasilopoulou E, Kilby MD. The role of the placenta in thyroid hormone delivery to the fetus. Nature clin. Pract. Endocrinol. \& Metab. 2009;5(1):45-54.

[60] Visser WE, Friesema ECH, Visser TJ. Minireview: Thyroid Hormone Transporters: The Knowns and the Unknowns. Mol. Endocrinol. 2011;25:1-14. 
[61] Friesema EC, Jansen J, Jachtenberg JW, Visser WE, Kester MH, Visser TJ. Effective cellular uptake and efflux of thyroid hormone by human monocarboxylate transporter 10. Mol. Endocrinol. 2008;22:1357-1369.

[62] Kester MH. The importance of thyroid hormone sulfation during fetal development. PhD Thesis, University of Erasmus, Netherlands; 2001. ISBN 90-9015010-2.

[63] Farooqui AA. 3'-Phosphoadenosine-5'-phosphosulfate metabolism in mammalian tissue. Int. J. of Biochem.1980;12:529-536.

[64] Visser TJ. The role of sulfation in thyroid hormone metabolism. Chemico-Biological Interactions 1994;92:292-303.

[65] Chopra IJ, Wu SY, Chua Teco GN, Santini F. A radioimmunoassay of 3,5,3'triiodothyronine sulfate: studies in thyroidal and nonthyroidal diseases, pregnancy, and neonatal life. J. Clin. Endocrinol. Metab. 1992;75:189-194.

[66] Santini F, Cortelazzi D, Baggiani AM, Marconi AM, Beck-Peccoz P, Chopra IJ. A study of the serum 3,5,3'-triiodothyronine sulfate concentration in normal and hypothyroid fetuses at various gestational stages. J. Clin. Endocrinol. Metab. 1993;76:1583-1587.

[67] Polk DH, Reviczky A, Wu SY, Huang WS, Fisher DA. Metabolism of sulfoconjugated thyroid hormone derivatives in developin sheep. Am. J. Physiol. 1994;266:E892-E898.

[68] Wu SY, Huang WS, Polk D, Chopra IJ. The development of a radioimmunoassay for reverse triiodothyronine sulfate in human serum and amniotic fluid. J. of Clin. Endocrinol.and Metab. 1993;76:1625-1630.

[69] Kester MHA, Kaptein E, Roest TJ, Hume R, Visser TJ. Characterisation of human iodothyronine sulfotransferases. J. of Clin. Endocrinol. and Metab. 1999;84:1357-1364.

[70] Parenti G, Meroni G, Ballabio A. The sulfatase gene family. Curr. Opin. in Gen. Dev. 1997;7:386-391.

[71] Friesema ECH, Docter R, Moerings EPCM, Stieger B, Hagenbuch B, Meier PJ, Krenning EP, Hennemann G, Visser TJ. Identification of thyroid hormone transporters. Biochem. Biophys. Res. Commun. 1999;254:497-501.

[72] Flamant F, Baxter JD, Forrest D, Refetoff S, Samuels H, Scanlan TS, Vennstrom B, Samarut J. International Union of Pharmacology. LIX. The pharmacology and classification of the nuclear receptor superfamily: thyroid hormone receptors. Pharmacol. Rev. 2006;58:705-711.

[73] Pascual A, Aranda A. Thyroid hormone receptors, cell growth and differentiation. Biochimica et Biophysica Acta 2012 xxx-xxx.

[74] Shi Y-B, Ritchieb JWA, Taylor PM. Complex regulation of thyroid hormone action: multiple opportunities for pharmacological intervention. Pharmacol. \& Therapeutics 2002;94:235- 251.

[75] Oetting A, Yen PM. New insights into thyroid hormone action. Best Pract. \& Res. Clin. Endocrinol. \& Metab. 2007;21(2):193-208.

[76] Schussler GC. The thyroxine-binding proteins. Thyroid 2000;10(2):141-149.

[77] Larsson A, Palm M, Hansson LO, Axelsson O. Reference values for clinical chemistry tests during normal pregnancy. BJOG 2008;115(7):874-881.

[78] Zhou A, Wei Z, Read RJ, Carrell RW. Structural mechanism for the carriage and release of thyroxine in the blood. Proc. Natl Acad. Sci. USA 2006;103(36):13321-13326. 
[79] Glinoer D. The regulation of thyroid function in pregnancy: pathways of endocrine adaptation from physiology to pathology. Endocr. Rev. 1997;18(3):404-433.

[80] Glinoer D, De Nayer P, Bourdoux P. Regulation of maternal thyroid during pregnancy. J. Clin. Endocrinol. Metab. 1990;71(2):276-287.

[81] Lee RH, Spencer CA, Mestman JH. Free T4 immunoassays are flawed during pregnancy. Am. J. Obstet. Gynecol. 2009;200(3):e1-e6.

[82] Kurioka H, Takahashi K, Miyazaki K. Maternal thyroid function during pregnancy and puerperal period. Endocr. J. 2005;52(5):587-591.

[83] De Vito P, Incerpi S, Pedersen JZ, Luly P, Davis FB, Davis PJ. Thyroid hormones as modulators of immune activities at the cellular level. Thyroid 2011;21:879-890.

[84] Chen C, Zhou Z, Zhong M, Li M, Yang X, Zhang Y, Wang Y, Wei A, Qu M, Zhang L, Xu $S$, Chen S, Yu Z. Excess thyroid hormone inhibits embryonic neural stem/progenitor cells proliferation and maintenance through STAT3 signalling pathway. Neurotox. Res. 2011;20:15-25.

[85] Contreras-Jurado C, Garcia-Serrano L, Gomez-Ferreria M, Costa C, Paramio JM, Aranda A. The thyroid hormone receptors as modulators of skin proliferation and inflammation. J. Biol. Chem. 2011;286:24079-24088.

[86] Blair AS, Hajduch E, Litherland GJ, Hundal HS. Regulation of glucose transport and glycogen synthesis in L6 muscle cells during oxidative stress. Evidence for cross-talk between the insulin and SAPK2/p38 mitogen-activated protein kinase signaling pathways. J. Biol. Chem. 1999;274:36293-36299.

[87] Bassett JHD, Harvey CB, Williams GR. Mechanisms of thyroid hormone receptorspecific nuclear and extra nuclear actions. Mol. and Cell. Endocrinol. 2003;213:1-11.

[88] Davis PJ, Shih A, Lin HY, Martino LJ, Davis FB. Thyroxine promotes association of mitogen-activated protein kinase and nuclear thyroid hormone receptor (TR) and causes serine phosphorylation of TR. J. Biol. Chem. 2000;275:38032-38039.

[89] Wrutniak-Cabello C, Casas F, Cabello G. Thyroid hormone action in mitochondria. J. Mol. Endocrinol. 2001;26:67-77.

[90] Incerpi S, Luly P, De Vito P, Farias RN. Short - term effects of thyroid hormones on the $\mathrm{Na} / \mathrm{H}$ antiport in L-6 myoblasts: high molecular specificity for 3,3',5-triiodothyronine. Endocrinol. 1999;140:683 - 689.

[91] De Vito P, Balducci V, Leone S, Percario Z, Mangino G, Davis FB, Davis PJ, Affabris E, Luly P, Pedersen JZ, Incerpi S. Nongenomic effects of thyroid hormones on the immune system cells: new targets, old players. Steroids 2012 xxx-xxx.

[92] Kavok NS, Krasilnikova, OA, Babenko, NA. Thyroxine signal transduction in liver cells involves phospholipase $\mathrm{C}$ and phospholipase $\mathrm{D}$ activation genomic independent action of thyroid hormone. BMC Cell. Biol. 2001;2:5.

[93] Incerpi S. Actions of thyroid hormones on ion transport. Curr. Op. Endocrinol. Diab. 2002;9:381-386.

[94] Lin HY, Sun M, Tang HY, Lin C, Luidens MK, Mousa SA, Incerpi S, Drusano GL, Davis FB, Davis PJ. L-Thyroxine vs. 3,5,3'-triiodo-L-thyronine and cell proliferation: activation of mitogen-activated protein kinase and phosphatidylinositol 3-kinase. Am. J. Physiol. Cell. Physiol. 2009;296:C980-991. 
[95] Bergh JJ, Lin HY, Lansing L, Mohamed SN, Davis FB, Mousa S, Davis PJ. Integrin alphaVbeta3 contains a cell surface receptor site for thyroid hormone that is linked to activation of mitogen-activated protein kinase and induction of angiogenesis. Endocrinol. 2005;146:2864-2871.

[96] Gnocchi D, Leoni S, Incerpi S, Bruscalupi G. 3,5,3'-Triiodothyronine ( $\mathrm{T}_{3}$ ) stimulates cell proliferation through activation of PI3K/Akt pathway and Reactive Oxygen Species (ROS) production in chick embryo hepatocytes. Steroids 2012 xxx-xxxx.

[97] Farwell AP, Dibenedetto DJ, Leonard JL. Thyroxine targets different pathways of internalization of type II iodothyronine 5'-deiodinase in astrocytes. J. Biol. Chem. 1993;268:50-55.

[98] Siegrist-Kaiser CA, Juge-Aubry, Tranter MP, Ekenbarger DM, Leonard JL. Thyroxinedependent modulation of actin polymerization in cultured astrocytes: a novel extranuclear action of thyroid hormone. J. Biol. Chem. 1990;26:5296-5302.

[99] Farwell AP, Safran M, Dubord S, Leonard JL. Degradation and recycling of the substrate-binding subunit of type II iodothyronine 5'-deiodonase in astrocytes. J. Biol. Chem. 1996;271:16369-16374.

[100] Farwell AP, Tranter MP, Leonard JL. Thyroxine-dependent regulation of integrinlaminin interactions in astrocytes. Endocrinol. 1995;136:3909-3915.

[101] Wang QW, Yu B, Huang RP, Cao F, Zhu ZQ, Sun DC, Zhou H. Assessment of thyroid function during pregnancy: the advantage of self-sequential longitudinal reference intervals. Arch Med. Sci. 2011;7(4):679-684.

[102] Brent GA. The debate over thyroid-function screening in pregnancy. N Engl J Med. 2012;366(6):562-563.

[103] Heather N, Hall K, Neas K, Potter H, Wiltshire E. Growth and development in a child with resistance to thyroid hormone and ectopic thyroid gland. Pediatr. 2012;129(3):e817e820.

[104] Lazarus JH, Bestwick JP, Channon S, Paradice R, Maina A, Rees R, Chiusano E, John R, Guaraldo V, George LM, Perona M, Dall'Amico D, Parkes AB,Joomun M, Wald NJ. Antenatal thyroid screening and childhood cognitive function. N. Engl. J. Med. 2012;366(6):493-501.

[105] Morreale de Escobar G, Pastor R, Obregón MJ, Escobar del Rey F. Effects of maternal hypothyroidism on the weight and thyroid hormone content of rat embryonic tissues before and after onset of fetal thyroid function. Endocrinol. 1985;117:1890-1901.

[106] Morreale de Escobar G, Obregón MJ, Ruiz de Oña C, Escobar del Rey F. Transfer of thyroxine from the mother to the rat fetus near term: effects on brain 3,5,3'triiodothyronine deficiency. Endocrinol. 1988;122(4):1521-1531.

[107] Falcone M, Miyamoto T, Fierro-Renoy F, Macchia E, DeGroot LJ. Evaluation of the ontogeny of thyroid hormone isotypes in rat brain and liver using an immunohistochemical technique. Eur. J. Endocrinol. 1994;130:97-106.

[108] Morreale de Escobar G, Obregón MJ, Escobar del Rey F. Is neuropsychological development related to maternal hypothyroidism or to maternal hypothyroxinemia? J. Clin. Endocrinol. Metab. 2000;85:3975-3987. 
[109] Ausó E, Lavado-Autric R, Cuevas E, Escobar del Rey F, Morreale de Escobar G, Berbel P. A moderate and transient deficiency of maternal thyroid function at the beginning of fetal neocorticogenesis alters neuronal migration. Endocrinol. 2004;145:4037-4047.

[110] Ferreiro B, Bernal J, Morreale de Escobar G, Potter BJ. Preferential saturation of brain T3 receptor during development in fetal lambs. Endocrinol. 1988;122:438-443.

[111] Chan S, Kilby MD. Thyroid hormone and central nervous system development. Endocrinol. 2000;165:1-8.

[112] Fantz CR, Dagogo-Jack S, Ladenson JH, Gronowski AM. Thyroid function during pregnancy. Clin. Chem. 1999;45:2250-2258.

[113] Zoeller RT. Editorial: Local control of the timing of thyroid hormone action in the developing human brain. J. Clin. Endocrinol. Metab. 2004;89(7):3114-3116.

[114] Zoeller RT, Crofton KM. Thyroid hormone action in fetal brain development and potential for disruption by environmental chemicals. Neurotoxicol. 2000;21(6):1-11.

[115] Zoeller RT, Rovett J. Timing of thyroid hormone action in the developing brain: Clinical observations and experimental findings. Neuroendocrinol. 2004;16:809-818.

[116] Anderson GW. Thyroid hormone and cerebellar development. Cerebellum 2008;7:6074.

[117] Nicholson JL, Altman J. The effects of early hypo- and hyperthyroidism on the development of the rat cerebellar cortex. II. Synaptogenesis in the molecular layer. Brain Res. 1972;44:25-36.

[118] Bernal J. In "Hormones, Brain and Behavior", Eds Arnold AP et al. Academic Press, 2002;4:543-587.

[119] Quignodon L, Grijota-Martinez C, Compe E, Guyot R, Allioli N, Laperrière D, Walker R, Meltzer P, Mader S, Samarut J, Flamant F. A combined approach identifies a limited number of new thyroid hormone target genes in post-natal mouse cerebellum. J. Mol. Endocrinol. 2007;39:17-28.

[120] Takahashi M, Negishi T, Tashiro T. Identification of genes mediating thyroid hormone action in the developing mouse cerebellum. J. Neurochem. 2008;104:640-652.

[121] Dong H, Yauk CL, Rowan-Carroll A, You SH, Zoeller RT, Lambert I, Wade MG. Identification of thyroid hormone receptor binding sites and target genes using ChIPon-chip in developing mouse cerebellum. PLoS ONE 2009;4:e4610.

[122] Anderson GW, Schoonover CM, Jones SA. Control of thyroid hormone action in the developing rat brain. Thyroid 2003;13:1039-1056.

[123] Lee PR, Brady D, Koenig JI. Thyroid hormone regulation of Nmethyl-D-aspartic acid receptor subunit mRNA expression in adult brain. J. Neuroendocrinol. 2003;15(1):87-92.

[124] Agrawal A, Diwan SK. Pituitary hyperplasia resulting from primary hypothyroidism. Asian J. Neurosurg. 2011;6(2):99-100.

[125] Burman KD. Thyroid function: Gestational hypothyroidism-a need for universal screening? Nat. Rev. Endocrinol. 2012 xxx-xxx.

[126] Celik C, Abali R, Tasdemir N, Guzel S, Yuksel A, Aksu E, Yılmaz M. Is subclinical hypothyroidism contributing dyslipidemia and insulin resistance in women with polycystic ovary syndrome? Gynecol. Endocrinol. 2012 xxx-xxx. 
[127] Danzi S, Klein I. Subclinical hypothyroidism and the heart: the beat goes on. Thyroid. 2012;22(3):235-236.

[128] Hashemipour M, Abari SS, Mostofizadeh N, Haghjooy-Javanmard S, Esmail N, Hovsepian S, Masoud A, Kelishadi R, Hasanzadeh A, Mirouliaei M. The role of maternal thyroid stimulating hormone receptor blocking antibodies in the etiology of congenital hypothyroidism in isfahan, iran. Int. J. Prev. Med. 2012;3(2):128-133.

[129] McCoy SS, Crowson CS, Gabriel SE, Matteson EL. Hypothyroidism as a Risk Factor for Development of Cardiovascular Disease in Patients with Rheumatoid Arthritis. J. Rheumatol. 2012 xxx-xxx.

[130] Perry KD, Hope J, Yang J. Dyshormonogenetic goiter-like changes in a child with congenital hypothyroidism and a euthyroid adult. Diagn. Cytopathol. 2012 xxx-xxx.

[131] Resta F, Triggiani V, Barile G, Benigno M, Suppressa P, Giagulli VA, Guastamacchia E, Sabbà C. Subclinical Hypothyroidism and Cognitive Dysfunction in the Elderly. Endocr. Metab. Immune Disord Drug Targets. 2012 xxx-xxx.

[132] Shamshiri AR, Yarahmadi S, Forouzanfar MH, Haghdoost AA, Hamzehloo G, Holakouie Naieni K. Evaluation of Current Guthrie TSH Cut-off Point in Iran Congenital Hypothyroidism Screening Program: A Cost-Effectiveness Analysis. Arch Iran Med. 2012;15(3):136-141.

[133] Péter F, Muzsnai A. Congenital disorders of the thyroid: hypo/hyper. Pediatr. Clin. North Am. 2011;58(5):1099-1115.

[134] Rugge B, Balshem H, Sehgal R, Relevo R, Gorman P, Helfand M. Screening and Treatment of Subclinical Hypothyroidism or Hyperthyroidism [Internet]. Agency for Healthcare Research and Quality (US); 2011;11(12)-EHC033-EF.

[135] Czyzewska U, Tylicki A, Siemieniuk M, Strumilo S. Changes of activity and kinetics of certain liver and heart enzymes of hypothyroid and T(3)-treated rats. J. Physiol. Biochem. 2012 xxx-xxx.

[136] Pearce EN. Iodine-induced thyroid dysfunction: comment on "association between iodinated contrast media exposure and incident hyperthyroidism and hypothyroidism". Arch Intern. Med. 2012;172(2):159-161.

[137] Rhee CM. Association between iodinated contrast media exposure and incident hyperthyroidism andhypothyroidism. Arch Intern. Med. 2012;172(2):153-159.

[138] Jaeggi ET, Roman KS. Maternal autoimmune disease and its impact on the fetal heart: management and prognosis. Prog. Pediatr. Cardiol. 2006;22:85-93.

[139] Zimmerman D. Fetal and neonatal hyperthyroidism. Thyroid 1999;9:727-733.

[140] Momotani N, Noh J, Ishikawa N, Ito K. Relationship between silent thyroiditis and recurrent Graves' disease in the postpartum period. J. Clin. Endocrinol. Metab. 1994;79:285-289.

[141] Marx H, Amin P, Lazarus JH. Hyperthyroidism in pregnancy. BMJ 2008;336:663-667.

[142] Laurberg P, Bournaud C, Karmisholt J, Orgiazzi J. Management of Graves' hyperthyroidism in pregnancy: focus on both maternal and foetal thyroid function, and caution against surgical thyroidectomy in pregnancy. Eur. J. Endocrinol. 2009;160:1-8.

[143] Mestman JH. Hyperthyroidism in pregnancy. Best Pract. Clin. Endocrinol. Metab. 2004;18:267-288. 
[144] Gärtner R. Thyroid diseases in pregnancy. Curr. Opin. Obstet. Gynecol. 2009;21:501507.

[145] Chiniwala NU, Woolf PD, Bruno CP. Thyroid storm caused by a partial hydatidiform mole. Thyroid 2008;18:479-481.

[146] McDermott MT, Ridgway EC. Central hyperthyroidism. Endocrinol. Metab. Clin. North Am. 1998;27(1):187-203.

[147] Cooper DS 2003. Hyperthyroidism. Lancet 2003;362:459-468.

[148] Panzer C, Beazley R, Braverman L. Rapid preoperative preparation for severe hyperthyroid Graves' disease. J. Clin. Endocrinol. Metab. 2004;89: 2142-2144.

[149] Reid JR, Wheeler SF. Hyperthyroidism: Diagnosis and treatment. Am. Fam. Phys. 2005;72(4):623-630.

[150] Matsuura N, Konishi J, Fujeda K, Iida Y, Fujimoto S, Kasagi K, Hagisawa M, Fukushi M, Takasugi N. TSH-receptor antibodies in mothers with Graves' disease and outcome in their offspring. Lancet 1988;2:14.

[151] Legrand J. Thyroid hormone effects on growth and development. In: Hennemann G (ed) Thyroid Hormone Metabolism. Marcel Dekker, Inc., New York, 1986; 503-534.

[152] Shambaugh GE. Biologic and cellular effects. In: Ingbar SH, Braverman LE (eds) Werner's The Thyroid: A Fundamental and Clinical Text, $5^{\text {th }}$ ed. J.B. Lippincott Co., Philadelphia, 1986; 201-218.

[153] Visser TJ. Metabolism of thyroid hormones. In: Cooke BA, King RJB, van der Molen HJ (eds) Hormones and their Action, Part 1. Elsevier Science Publishers, New York, 1988; 81-103.

[154] Galton VA. The Roles of the Iodothyronine Deiodinases in Mammalian Development. Thyroid 2005;15(8):832-834.

[155] Leonard JL, Visser TJ. Biochemistry of deiodination. In: Hennemann G (ed) Thyroid Hormone Metabolism. Marcel Dekker, New York, 1986;189-229.

[156] Porterfield SP, Hendrich CE. The role of thyroid hormones in prenatal and neonatal neurological development-Current perspectives. Endocr. Rev. 1993;14:94-106.

[157] Valverde RC, Aceves C, Reyes ZE. Ontogenesis of iodothyronine deiodinase activities in brain and liver of the chick embryo. Endocrinol. 1993;132:867-872.

[158] Darras VM, Visser TJ, Berghman LR, Kühn ER. Ontogeny of type I and type III deiodinase activities in embryonic and posthatch chicks: Relationship with changes in plasma triiodothyronine and growth hormone levels. Comp. Biochem. Physiol. 1992;103A:131-136.

[159] Darras VM, Robert H, Visser TJ. Regulation of thyroid hormone metabolism during fetal development. Mol. \& Cell. Endocrinol. 1999;151:37-47.

[160] Darras VM, Verhoelst CHJ, Reyns GE, Kühn ER, Van der Geyten S. Thyroid Hormone Deiodination in Birds. Thyroid 2006;16(1):25-35.

[161] Darras VM, Van Herck SLJ, Geysens S, Reyns GE. Involvement of thyroid hormones in chicken embryonic brain development. Gen. and Comp. Endocrinol. 2009;163:58-62.

[162] Darras VM, Van Herck SLJ, Heijlen M, De Groef B. Thyroid Hormone Receptors in Two model Species for Vertebrate Embryonic Development: Chicken and Zebrafish. J. Thyroid Res. 2011;1-8. 
[163] Van der Geyten S, Segers I, Gereben B, Bartha T, Rudas P, Larsen PR, Kühn PR, Darras VM. Transcriptional regulation of iodothyronine deiodinases during embryonic development. Mol. \& Cell. Endocrinol. 2001;183:1-9.

[164] Van der Geyten S, Van den Eynde I, Segers IB, Kühn ER, Darras VM. Differential expression of iodothyronine deiodinases in chicken tissues during the last week of embryonic development. Gen. and Comp. Endocrinol. 2002;128:65-73.

[165] Verhoelst CHJ, Vandenborne K, Severi T, Bakker O, Zandieh Doulabi B, Leonard JL, Kühn ER, Van der Geyten S, Darras VM. Specific detection of type III iodothyronine deiodinases protein in chicken cerebellar Purkinje cells. Endocrinol. 2002;143:2700-2707.

[166] Verhoelst CHJ, Darras VM, Zandieh Doulabi B, Reyns G, Kühn ER, Van der Geyten S. Type I iodothyronine deiodinases in euthyroid and hypothyroid chicken cerebellum. Mol. and Cell. Endocrinol. 2004;214:97-105.

[167] Verhoelst CHJ, Roelens SA, Darras VM. Role of spatiotemporal expression of iodothyronine deiodinase proteins in cerebellar cell organization. Brain Res. Bulletin 2005;67:196-202.

[168] Reyns GE, Venken K, Morreale de Escobar G, Kühn ER, Darras VM. Dynamics and regulation of intracellular thyroid hormone concentrations in embryonic chicken liver, kidney, brain, and blood. Gen. and Comp. Endocrinol. 2003;134:80-87.

[169] Scapin S, Leoni S, Spagnuolo S, Fiore AM, Incerpi S. Short-term effects of thyroid hormones on the $\mathrm{Na}^{+}-\mathrm{K}^{+}$ATPase activity of chick embryo hepatocytes during development: Focus on signal transduction. Am. J. Physiol. Cell. Physiol. 2009;296:C4C12.

[170] Grommen SV, Iwasawa A, Beck V, Darras VM, De Groef B. Ontogenic expression profiles of thyroid-specific genes in embryonic and hatching chicks. Domest. Anim. Endocrinol. 2011;40(1):10-18. 